أثثر ممارسة العروض الرياضية في بعض الذكاءات المتعددة وعلاقتها بمستوي الأداء لدي طلاب كلية التربية الرياضية.

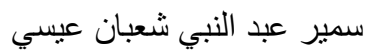
قسم تدريب التمرينات و الجمباز - كلية التربية الرياضية للبنين - جامعة الإسكندرية- جمهورية مصر العربية.

المقدمة ومثكلة البحث

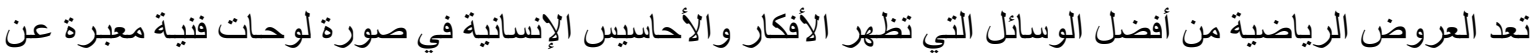

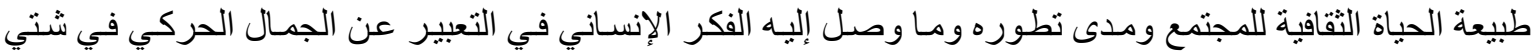

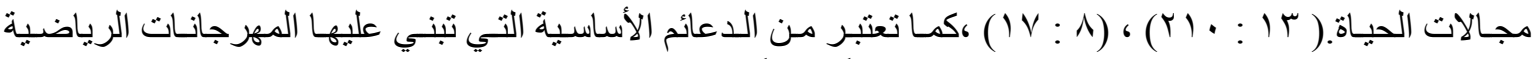

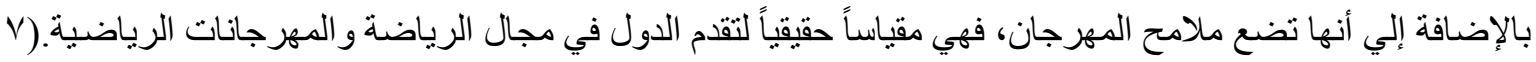

(rV: 11$)(1 \%$ :

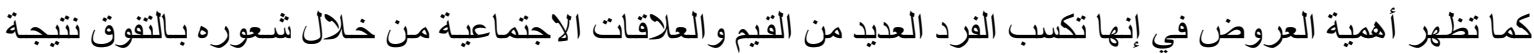

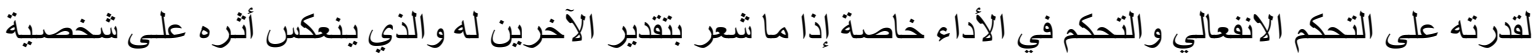

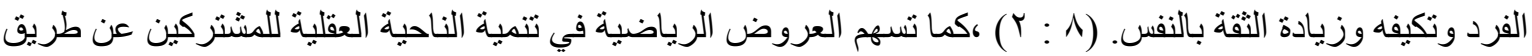

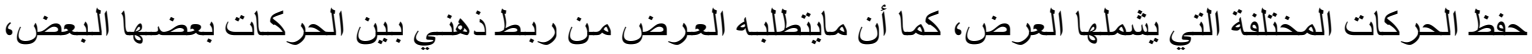

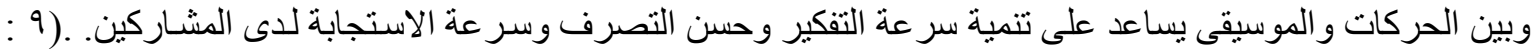

(1)1 - 117

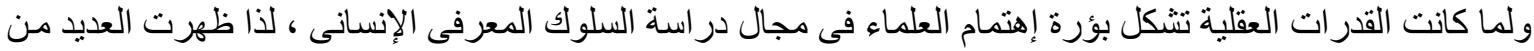

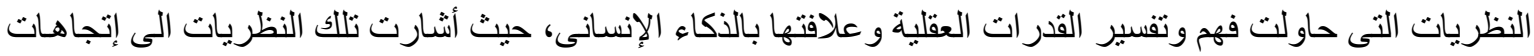

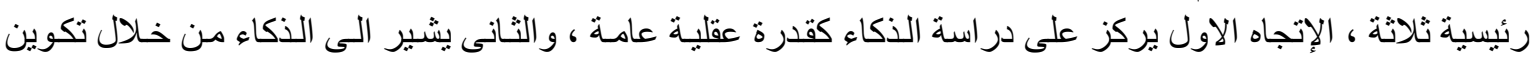

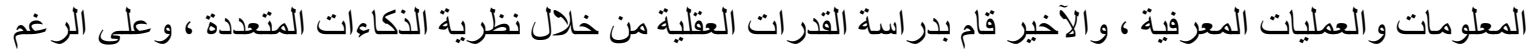

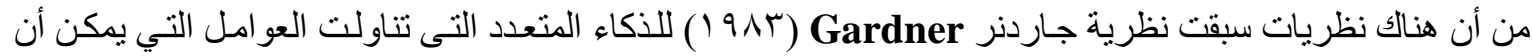

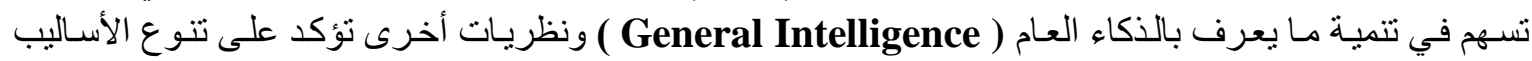

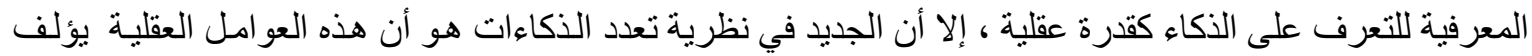

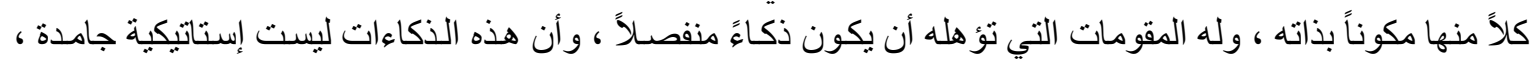

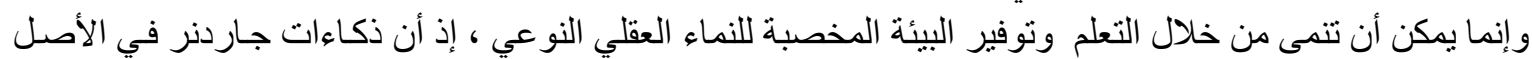

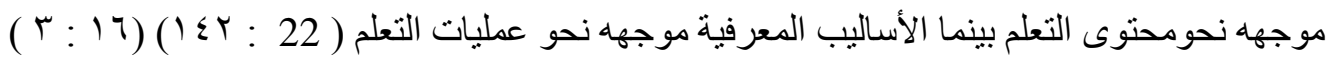

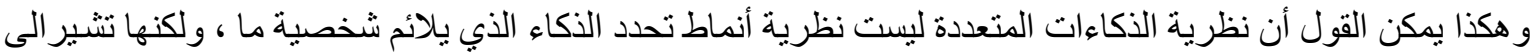

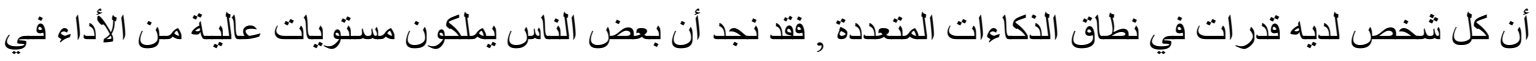

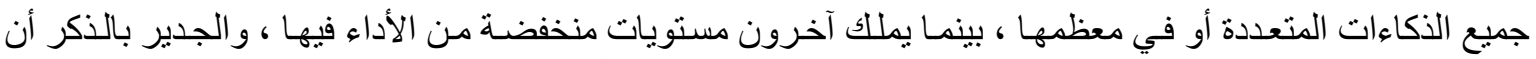

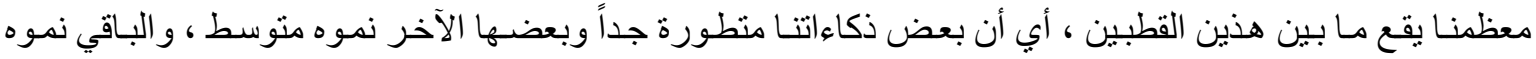

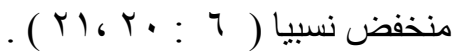

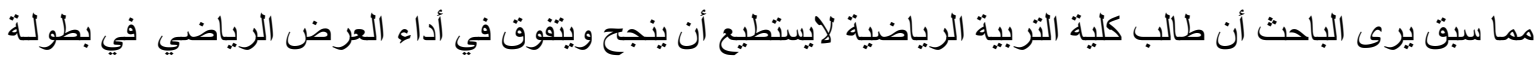

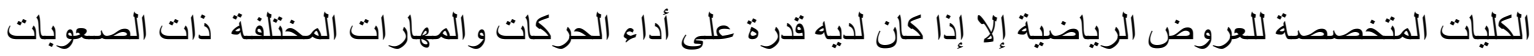

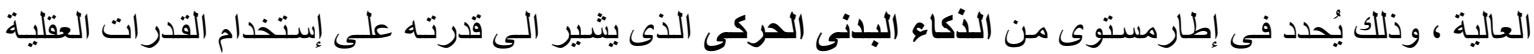

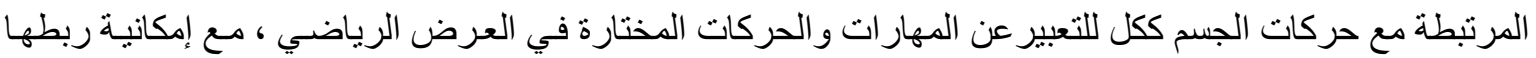


مـع إيقاعـات موسيقية متنو عـة ومتتاليـة والتى تعنى القدرة على إدر الك و إنتاج وتقدير الإيقاعـات الموسيقية المختلفـة

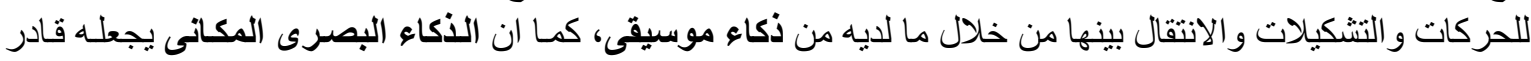

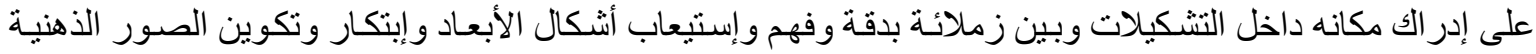

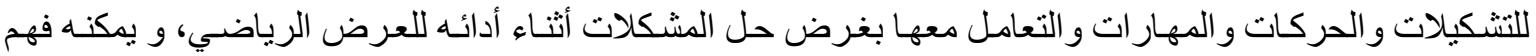

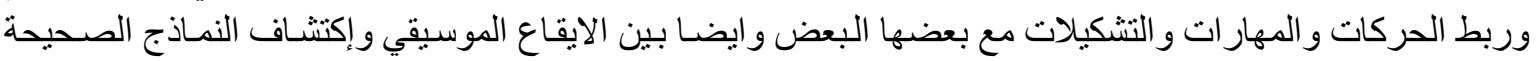

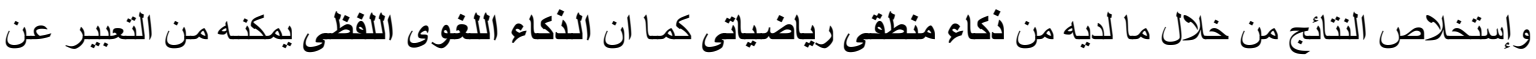

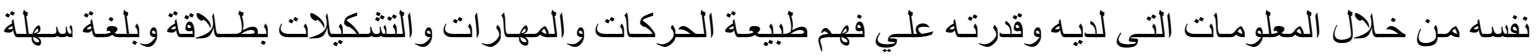

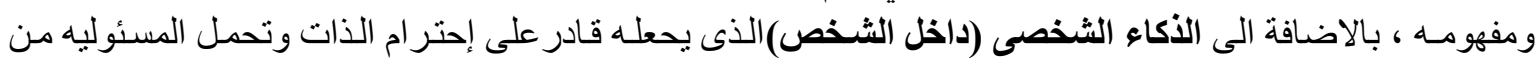

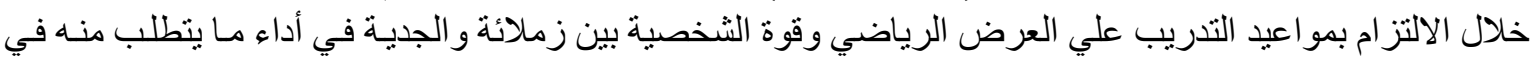

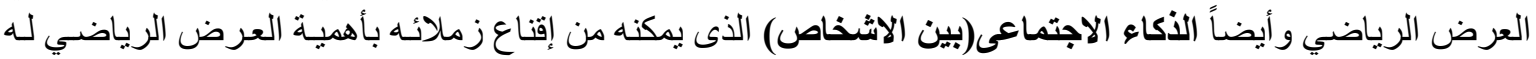

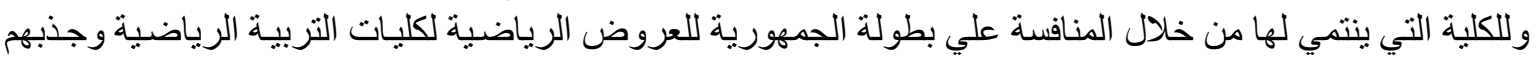

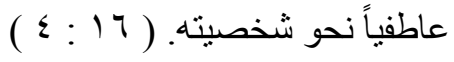

ومن خلال عرض الباحث لتطبيقات الذكاءات المتعددة لجاردنر Gardner فى المجال الرياضسى يمكن أن بستخلص

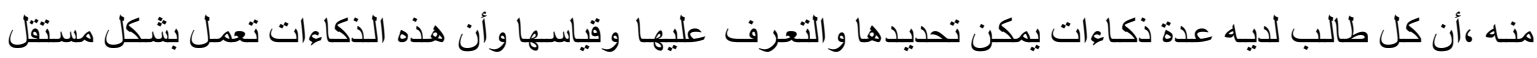

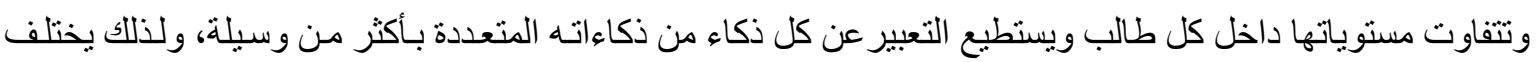

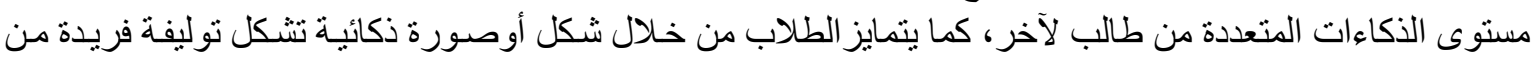

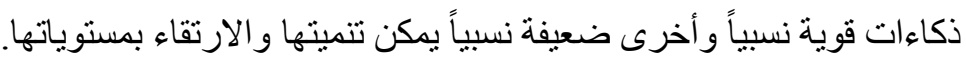
ولذلك يقوم الباحث مـن خـلال تلك الدر اسـة بـالتعرف على تأثير العروض الرياضية علـي بعض الذكاءات المتعددة و علاقتها بتحسين مستوي الأداء لدي طلاب كلية التربية الرياضية للبنين.

هدف البحث

يهدف البحث إلى التعرف على أثر ممارسة العروض الرياضية في بعض الأكاءات المتعددة وعلاقتها بمستوي الأداء

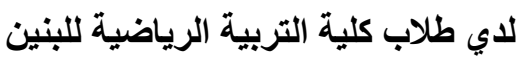
فروض البحث

ـ توجد فروق ذات دلاله إحصائية بين قياسات البحث الثلاثة (القبلي و البيني و البعدي) لدى المجمو عـة التجريبية في بعض الذكاءات المتعددة لدي طلاب كلية التربية الرياضية للبنين. - توجد فروق ذات دلاله إحصائية بين القياسين القبلي والبعدي لدى المجمو عة التجريبية في مستوى الأداء في العرض الرياضي لدي طلاب كلية التربية الرياضية للبنين. - توجد هناك علاقة ارتباطية دالة إحصائياً بين الذكاءات المتعددة و مستوى الأداء في العرض الرياضي لدي طلاب كلية التربية الرياضية للبنين.

مصطلحات البحث

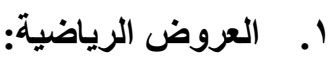

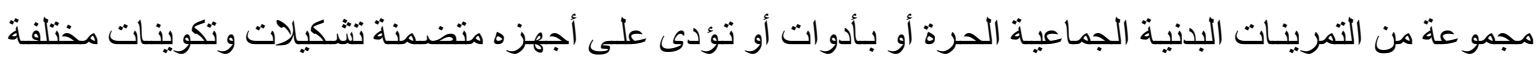

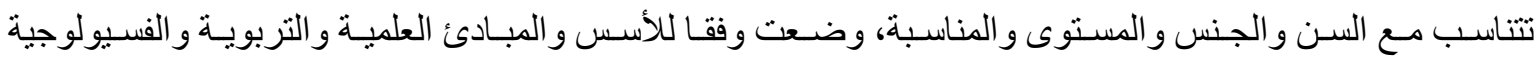

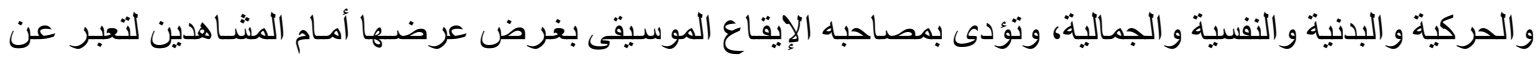

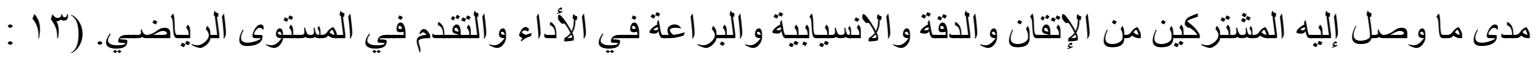


r ب. الأكاءات المتعددة فى ضوء تصنيف جاردنر :

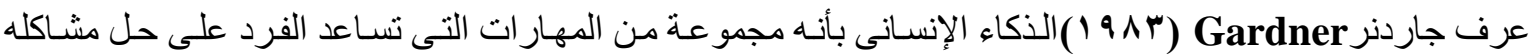

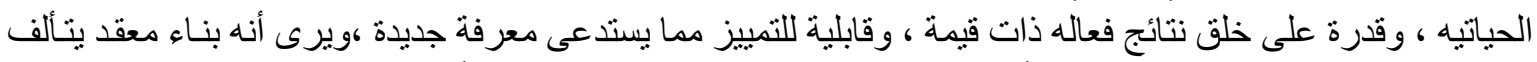

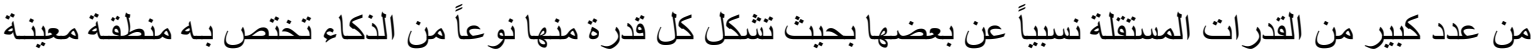

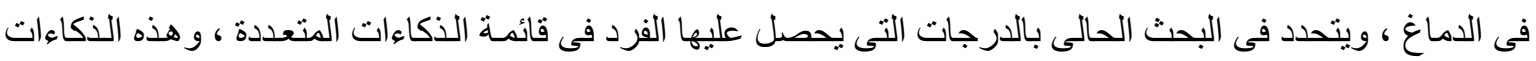

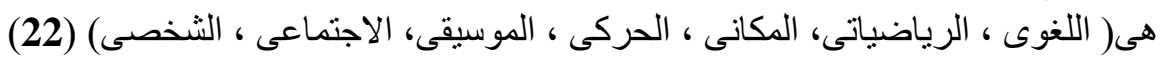

إجراءات البحث: - 20

المجال المكاني:ملاعب كلية التربية الرياضية للبنين بالإسكندرية.

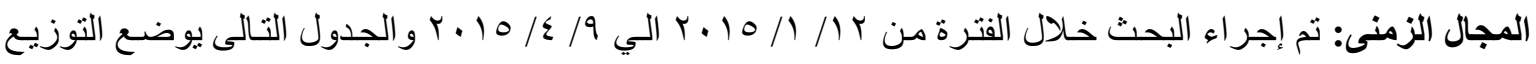

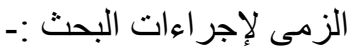

جدول (1)

التوزيع الزمنى لإجراءات البحث

\begin{tabular}{|c|c|}
\hline الفترة الزمنية الفية & الإجراءات \\
\hline 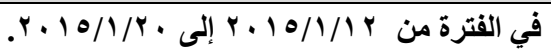 & أجريت الدراسة الإستطلاعية الأولى \\
\hline 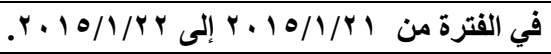 & تم إجراء القياسات القبلية \\
\hline 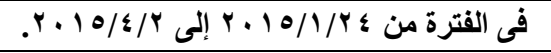 & تم إجراء التجربة الأساسية \\
\hline في يوم צr/r & تم إجراء القياسات القبلية لتقييم مستوى الأداء في العرض الرياضي \\
\hline 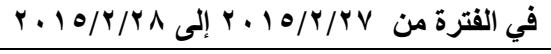 & تم إجراء القياسات البينية \\
\hline 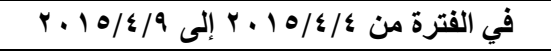 & تم إجراء القياسات البعدية \\
\hline
\end{tabular}

المجال البشرى:

طلاب الفرقة الثالثة بكلية التربية الرياضية للبنين - جامعة الإسكندرية . منهج البحث:

المــهج التجريبـي لملاعمتهـ لطبيعـة الدر اسـة، حيـث اتبـع الباحثث التصـيم التجريبـي ذو المجموعـة الواحدة بإسـتخدام القياسات القبلية و البينية و البعدية.

عينة البحث:

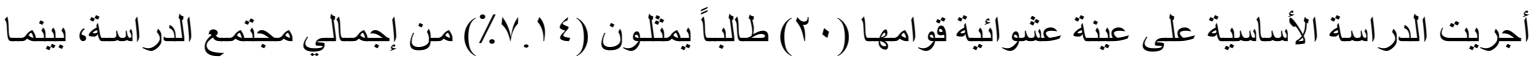

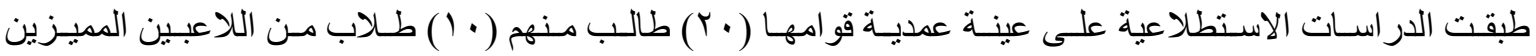
الممارسين للأنشطة الرياضية المختلفة.

الاراسات الاستطلاعية: الاراسة الاستطلاعية الأولى: أجريت بهرف: - تحديد الاختبار المناسب لقياس الذكاءات المتعددة. - حساب المعاملات العلمية (الصدق - الثبات ) لمقياس الذكاءات المتعددة . 


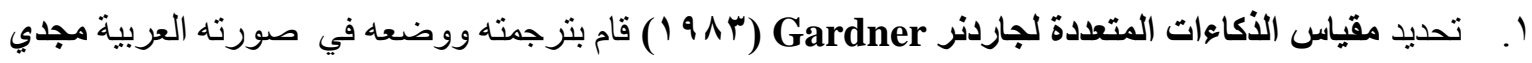

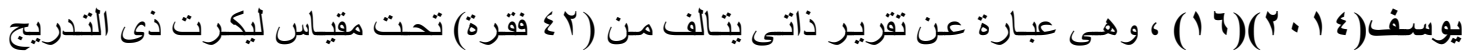

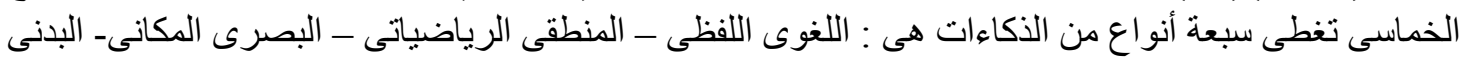

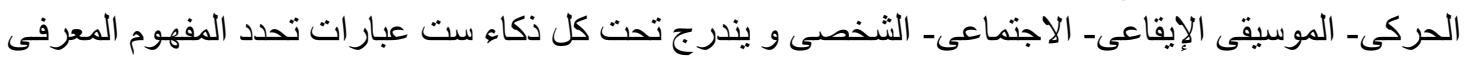

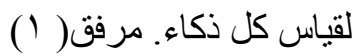

r. ت تم حساب المعاملات العلمية (الصدق - الثبات ) لمقياس الذكاءات المتعددة .مرفق (r)

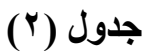

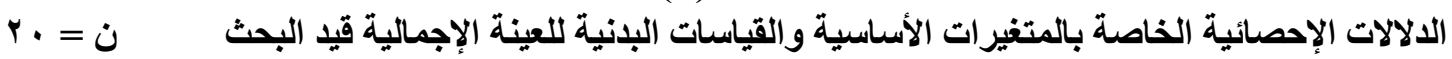

\begin{tabular}{|c|c|c|c|c|c|}
\hline معامل الاختلاف & معامل الالتواء & الانحراف & المتوسط & وحدة & الدلالات الإحصائية \\
\hline$\%$ & معامل الالوتواء & المعياري & الحسابي & القياس & المتغيرات الأسساسية \\
\hline 6.99 & $\cdot \wedge \Lambda_{-}$ & 1.54 & $19 . \leqslant V$ & (سنة) & السـن \\
\hline 4.37 & $1 . r \Lambda$ & $\mathrm{V} .7 \mathrm{~V}$ & $1 \times 0.00$ & (سم) & الطول \\
\hline 5.22 &. $.1 V_{-}$ & r.TV & $V \cdot . r \varepsilon$ & (كجم) & الــوزن \\
\hline
\end{tabular}

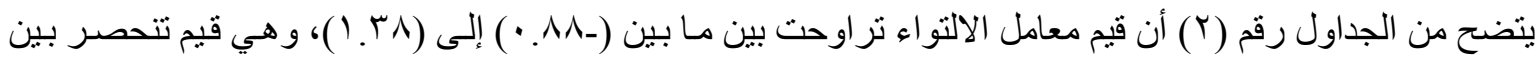

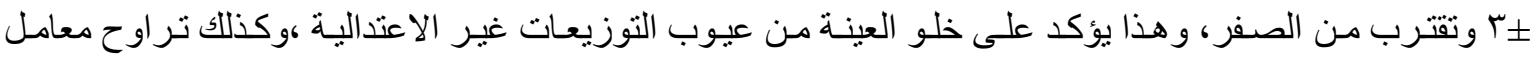

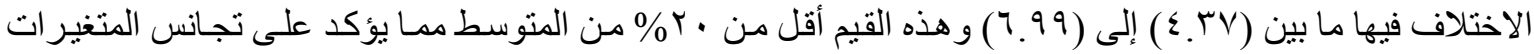
الأساسية الخاصة بالعينة قيد البحث قبل التجربة.

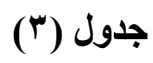

الالالات الإحصائية الخاصة بقائمة الذكاءات المتعدة لعينة الإجمالية قيد البحث ن = ج ج

\begin{tabular}{|c|c|c|c|c|c|c|}
\hline الاختلاف \%عل \% & معامل التفلطح & معامل الالتواء & المعياري & الحستوسط & القياس & الذكاءات المتعددة الدالات الإحصائية \\
\hline 2.22 & -1.23 & $\mathbf{0 . 8 3}$ & 0.39 & 17.43 & درجة & الأكاء اللغوي \\
\hline 4.02 & -0.99 & 0.52 & 0.71 & 17.64 & درجة & الذكاء الرياضياتى \\
\hline 4.74 & -1.48 & -0.37 & 0.86 & 18.23 & درجة & الأكاء المكاني \\
\hline 5.80 & -1.11 & 0.40 & 1.05 & 18.13 & درجة & الأكاء الحركي \\
\hline 4.26 & -1.97 & -0.03 & 0.73 & 17.24 & درجة & الأكاء الموسيقى \\
\hline 5.54 & -0.07 & 0.41 & 1.05 & 18.95 & درجة & الأكاء الإجتماعى \\
\hline 5.55 & -0.78 & -0.22 & 1.05 & 18.89 & درجة & الأكاء الثخصي \\
\hline 0.92 & -0.62 & $\mathbf{0 . 0 0}$ & 1.16 & 126.52 & درجة & مجموع الأكاءات المتعددة \\
\hline
\end{tabular}

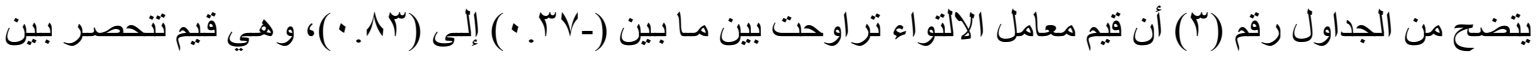

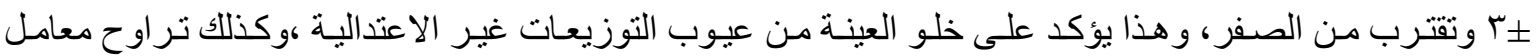

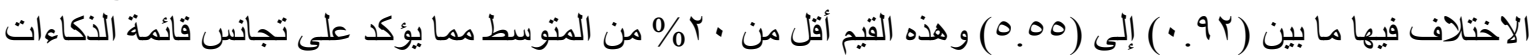
المتعددة الخاصة بالعينة قبد البحث قبل التجربة.

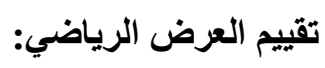

تم من خلال لجنة من أعضاء هيئة التدريس بقسم تدريب التمرينات و الجمباز بكلية التربية الرياضية للبنين بالإسكندرية

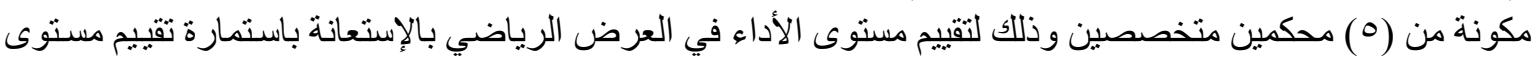

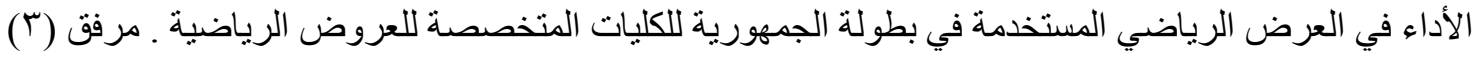




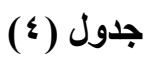

الالالات الإحصائية الخاصة باستمارة تقييم المحكمين لعينة البحث في منتصف التجربة (القياس القبلي) (ن=ه)

\begin{tabular}{|c|c|c|c|c|c|c|c|}
\hline $\begin{array}{c}\text { معامل الاختلاف } \\
\text { \% }\end{array}$ & التقلطح & الالتواء & 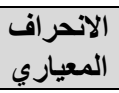 & ال المستوسط & درجة العنصر & \multicolumn{2}{|c|}{ محاور تقييم العرض الرياضىى الالات الإحصائية } \\
\hline 14.55 & .171 & -1.94 & 0.39 & 2.68 & 0 درجات & الاخول & \multirow{3}{*}{ المحور الأول } \\
\hline 2.33 & .001 & 2.24 & 0.18 & 7.68 & | 10 درجة & التكوينات و التثكيلات & \\
\hline 4.40 & 2.82 & -1.49 & 0.46 & 10.36 & ب درجة & المجموع & \\
\hline 8.33 & 1.17 & -1.94 & 0.39 & 4.68 & 1 1 درجات & الأداء المتسلسل & \multirow{5}{*}{ (الأداء القنى ) } \\
\hline 7.55 & 1.26 & -1.84 & $\mathbf{0 . 3 0}$ & 4.02 & 1 1 درجات & انسيابية الحركة & \\
\hline 6.67 & 2.00 & 2.14 & 0.18 & 2.68 & 1 1 درجات & الصعوبات & \\
\hline 2.66 & -1.33 & -0.61 & 0.11 & 4.12 & 1 1 درجات & التوظيف الجيا للأدوات & \\
\hline 3.53 & -1.88 & 0.08 & 0.55 & 15.50 & r r r r & المجموع & \\
\hline 7.21 & -1.33 & -0.61 & 0.55 & 7.60 & • 1 درجات & الملابس & \multirow{3}{*}{ المحور الثالث } \\
\hline 6.00 & 1.91 & 0.54 & 0.72 & 11.92 & ا 10 درجة & الموسيقى & \\
\hline 2.95 & -2.85 & -0.59 & 0.58 & 19.52 & كץ درجة & المجموع & \\
\hline 1.86 & -1.33 & 0.61 & 0.22 & 11.76 & ا 10 درجة & الإخراج & \multirow{4}{*}{ المحور الرابع } \\
\hline $\mathbf{0 . 0 0}$ & 0.00 & 0.00 & $\mathbf{0 . 0 0}$ & 5.00 & 0 درجات & زمن العرض & \\
\hline 12.60 & -2.37 & 0.56 & 0.22 & 1.72 & ب ب درجات & الخروج & \\
\hline 1.93 & -0.23 & 0.60 & 0.36 & 18.48 & r r درجة & المجموع & \\
\hline 1.03 & -0.25 & 0.45 & 0.66 & 63.86 & . . ا درجة & \multicolumn{2}{|c|}{ الدرجة الكلية للعرض ( المجموع ) } \\
\hline
\end{tabular}

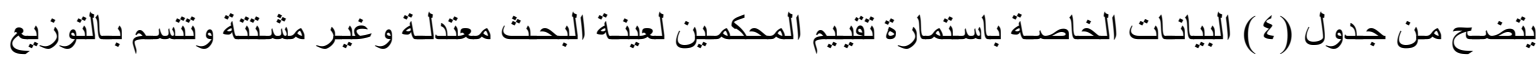

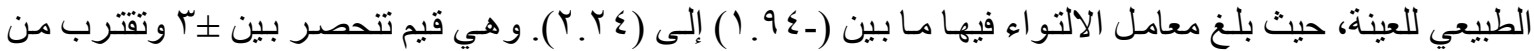

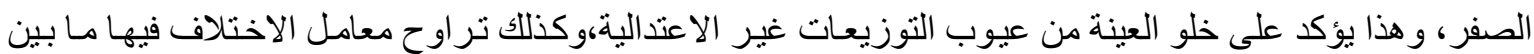

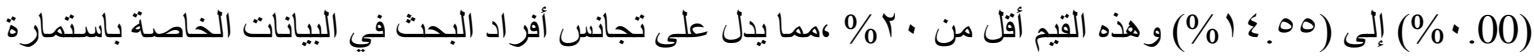
تقييم المحكمين بعد مرور خمسة أسابيع من بداية التجربة.

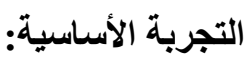

خضعت المجمو عة التجريية لبرنامج تعليمي تطبيقي للعرض الرياضي. مرفق (0)،(7). البرنامج التعليمي التتريبي للعرض الرياضي:

- خضعت مجموعة البحث في الأسبوع الأول إلى تعليم تمرينات وتطبيق حركات وتثكيلات العرض.

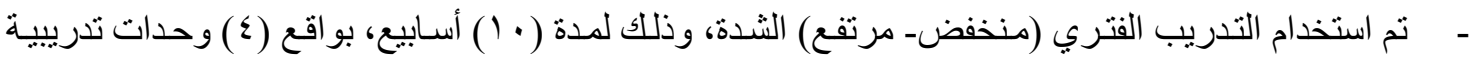

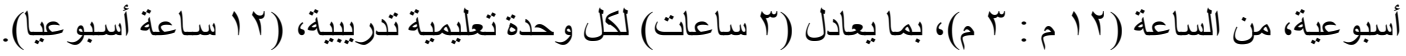

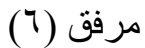

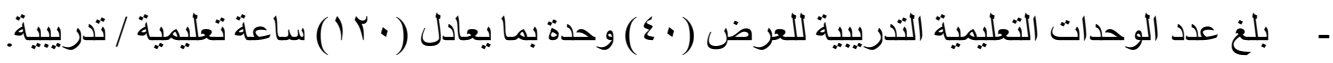

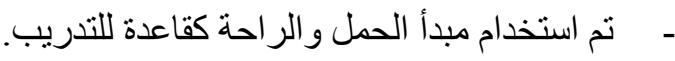
- زمن العرض (0) دقائق، يتكون من دخول - ( • (1) تشكيلات - خروج.

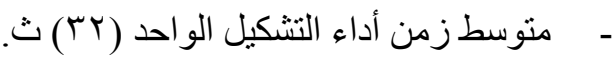

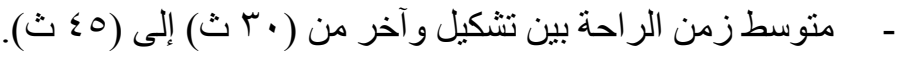


- متوسط زمن الر احة بين أداء مجمو عة التتكبلات بالوحدة التدريبية من (T ق) إلى (0 ق). - متوسط زمن الراحة بين أداء العرض كامل وأداؤه مرة أخرى (0 ق) إلى (10 ق).

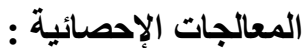
تم استخدام برنامج ال spss في إيجاد :

Stander deviation. - المتوسط الحسابى. Average - الانحر اف المعيارى Coefficient of Variation. معامل الاختلاف - معewness. - النسبة المئوية للتحسن. Percentile of improvement- معامل التفلطح مurtosis- مepeated Measures ANOVA -

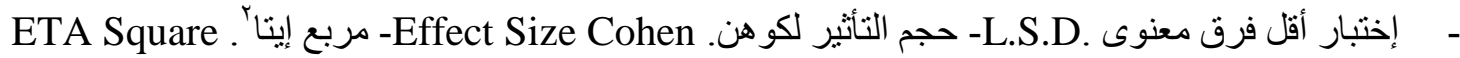

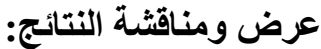

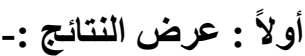

ا ا . عرض نتائج الذكاءات المتعده للمجموعة التجريبية خلال فترة التجربة :

جدول (•) (•)

الدلالات الإحصائية الخاصة بالذكاءات المتعدة لدى قياسات البحث الثلاثة خلال فترة التجربة للمجموعة التجريبية

\begin{tabular}{|c|c|c|c|c|c|c|c|}
\hline \multicolumn{2}{|c|}{ القياس البعدي } & \multicolumn{2}{|c|}{ القياس البيني } & \multicolumn{2}{|c|}{ القياس القبلي } & \multirow{2}{*}{ والقياس } & \multirow{2}{*}{ الذكاءات اللالعددات الإحصائية } \\
\hline$\varepsilon \pm$ & س- & $\varepsilon^{ \pm}$ & س- - & $\varepsilon^{ \pm}$ & س- & & \\
\hline 1.15 & 24.20 & 1.05 & 20.05 & 0.39 & 17.43 & (درجة) & الأكاء اللغوي \\
\hline 1.57 & 23.65 & 1.10 & 19.72 & 0.71 & 17.64 & (درجة) & الأكاء الرياضياتى \\
\hline 1.38 & 24.70 & 1.18 & 20.35 & 0.86 & 18.23 & (درجة) & الأكاء المكاني \\
\hline 1.42 & 25.30 & 1.20 & 20.53 & 1.05 & 18.13 & (درجة) & الأكاء الحركي \\
\hline 1.84 & 25.35 & 1.50 & 20.15 & 0.73 & 17.24 & (درجة) & الأكاء الموسيقى \\
\hline 1.57 & 25.55 & 0.72 & 21.75 & 1.05 & 18.95 & (درجة) & الأكاء الإجنماعى \\
\hline 1.39 & 25.71 & 1.33 & 21.42 & 1.05 & 18.89 & (درجة) & الأكاء الثخصي \\
\hline 3.59 & 174.46 & 3.35 & 143.97 & 1.16 & 126.52 & (درجة) & مجموع الأكاءات المتعددة \\
\hline
\end{tabular}


شكل (1) (1) (1)

المتوسطات الحسابية الخاصة بالذكاءات المتعددة قيد البحث لاى قياسات البحث الثلاثة خلال فترة التجربة للمجموعة التجريبية

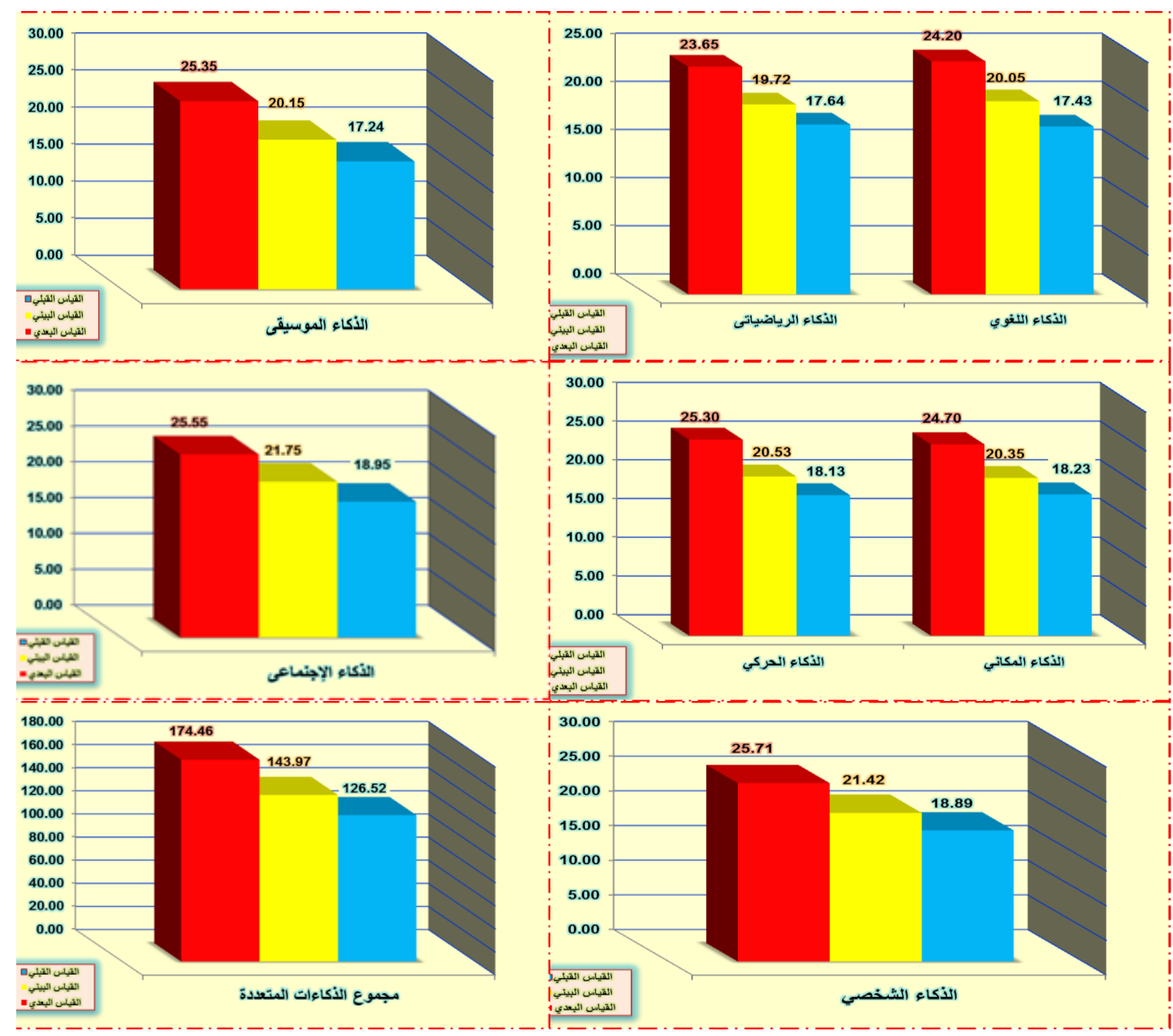

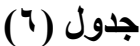

تحليل التباين الخاص بالذكاءات المتعدة لاى قياسات البحث الثلاثة خلال التجربة للمجموعة التجريبية.

\begin{tabular}{|c|c|c|c|c|c|c|c|}
\hline التأثنيز & الدستوي & قيمة ف ) & المربعات & الحرية & (القياسوات الثُلاثة) & الدلالات الإإحصائية & الذكاءات المتعددز \\
\hline \multirow[b]{2}{*}{0.999} & \multirow[b]{2}{*}{0.00} & \multirow[b]{2}{*}{ *29032.59 } & 25364.46 & 1.00 & 25364.46 & التأثير بين القياسات & \multirow{4}{*}{ الأكاء اللغوي } \\
\hline & & & 0.87 & 19.00 & 16.60 & الخطأ للعامل بين & \\
\hline \multirow[b]{2}{*}{0.935} & \multirow[b]{2}{*}{0.00} & \multirow[b]{2}{*}{$* 273.21$} & 232.94 & 2.00 & 465.88 & التأثير داخل القياسات & \\
\hline & & & 0.85 & 38.00 & 32.40 & الخطأ للعامل داخل & \\
\hline
\end{tabular}




\begin{tabular}{|c|c|c|c|c|c|c|c|}
\hline التأثيرم & مستوى & قيمة ف ) & المربعات & الحرية & (القياسات الثثلاثة) & الالالات الإحصائية & الأكاءات المتعددة \\
\hline \multirow[b]{2}{*}{0.999} & \multirow[b]{2}{*}{0.00} & \multirow[b]{2}{*}{ *19881.98 } & 24814.80 & 1.00 & 24814.80 & التأثثير بين القياسات & \multirow{4}{*}{ الرياضياتى الأكاء } \\
\hline & & & 1.25 & 19.00 & 23.71 & الخطأ للعامل بين & \\
\hline \multirow[b]{2}{*}{0.871} & \multirow[b]{2}{*}{0.00} & \multirow[b]{2}{*}{$* 127.76$} & 186.22 & 2.00 & 372.44 & التأثير داخل القياسات & \\
\hline & & & 1.46 & 38.00 & 55.39 & الخطأ للعامل داخل & \\
\hline \multirow[b]{2}{*}{0.999} & \multirow[b]{2}{*}{0.00} & \multirow[b]{2}{*}{$* 16523.22$} & 26695.72 & 1.00 & 26695.72 & التأثير بين القياسات & \multirow{4}{*}{ الأكاء المكاني } \\
\hline & & & 1.62 & 19.00 & 30.70 & الخطأ للعامل بين & \\
\hline \multirow[b]{2}{*}{0.904} & \multirow[b]{2}{*}{0.00} & \multirow[b]{2}{*}{ *178.76 } & 217.59 & 2.00 & 435.19 & التأثير داخل القياسات & \\
\hline & & & 1.22 & 38.00 & 46.25 & الخطأ للعامل داخل & \\
\hline \multirow[b]{2}{*}{0.999} & \multirow[b]{2}{*}{0.00} & \multirow[b]{2}{*}{$* 30476.30$} & 27272.54 & 1.00 & 27272.54 & التأثير بين القياسات & \multirow{4}{*}{ الأكاء الحركي } \\
\hline & & & 0.89 & 19.00 & 17.00 & الخطأ للعامل بين & \\
\hline \multirow[b]{2}{*}{0.885} & \multirow[b]{2}{*}{0.00} & \multirow[b]{2}{*}{$* 145.70$} & 266.41 & 2.00 & 532.81 & التأثير داخل القياسات & \\
\hline & & & 1.83 & 38.00 & 69.48 & الخطأ للعامل داخل & \\
\hline \multirow[b]{2}{*}{0.998} & \multirow[b]{2}{*}{0.00} & \multirow[b]{2}{*}{$* 9035.73$} & 26244.98 & 1.00 & 26244.98 & التأثير بين القياسات & \multirow{4}{*}{ الموسيقى الأكاء } \\
\hline & & & 2.90 & 19.00 & 55.19 & الخطأ للعامل بين & \\
\hline \multirow[b]{2}{*}{0.916} & \multirow[b]{2}{*}{0.00} & \multirow[b]{2}{*}{$* 206.21$} & 337.34 & 2.00 & 674.69 & التأثير داخل القياسات & \\
\hline & & & 1.64 & 38.00 & 62.16 & الخطأ للعامل داخل & \\
\hline \multirow[b]{2}{*}{0.999} & \multirow[b]{2}{*}{0.00} & & 29263.51 & 1.00 & 29263.51 & التأثير بين القياسات & \multirow{4}{*}{ الإجتماعى الأكاء } \\
\hline & & *15233.69 & 1.92 & 19.00 & 36.50 & الخطأ للعامل بين & \\
\hline & & & 219.71 & 2.00 & 439.42 & التأثير داخل القياسات & \\
\hline 0.915 & 0.00 & *203.96 & 1.08 & 38.00 & 40.93 & الخطأ للعامل داخل & \\
\hline & & & 29060.68 & 1.00 & 29060.68 & التأثير بين القياسات & \\
\hline 0.999 & 0.00 & $* 15343.51$ & 1.89 & 19.00 & 35.99 & الخطأ للعامل بين & \\
\hline & & & 237.27 & 2.00 & 474.53 & التأثير داخل القياسات & 180 \\
\hline 0.895 & 0.00 & *162.16 & 1.46 & 38.00 & 55.60 & الخطأ للعامل داخل & \\
\hline & & & 1319884.85 & 1.00 & 1319884.85 & التأثير بين القياسات & \\
\hline 1.000 & 0.00 & *250777.97 & 5.26 & 19.00 & 100.00 & الخطأ للعامل بين & مجموع \\
\hline & & & 11774.49 & 2.00 & 23548.98 & التأثير داخل القياسات & المتعددة \\
\hline 0.984 & 0.00 & $* 1163.52$ & 10.12 & 38.00 & 384.55 & الخطأ للعامل داخل & \\
\hline
\end{tabular}

قيمة ف الجدولية عند مستوى ه •. . بين القياسات = 4.38، داخل القياسات = •؟.ب . يتضح من الجدول رقم (0) ،(7) و الثكل البياني رقم (1) (1) جود فروق دالة احصائيا بين قياسات البحث الثناثة فى جميع

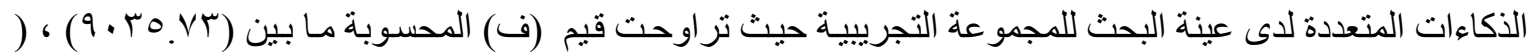




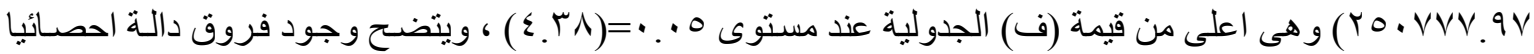

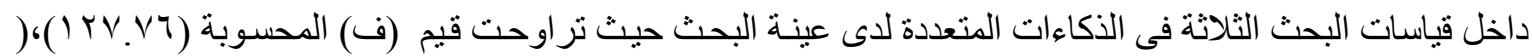

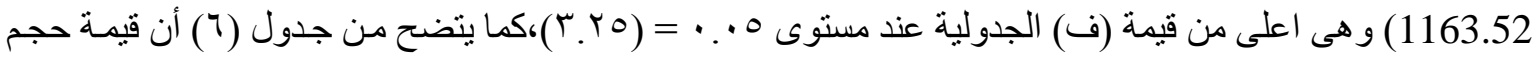

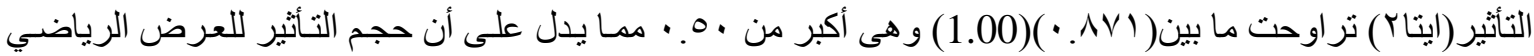

على الذكاءات المتعددة كان قويا.

\section{(V) جدول}

أقل فرق معنوى "LSD" للفروق بين متوسطات الاكاعات المتعددة لاى قياسات البحث الثلاثة خلال فترة التجربة للمجموعة التجريبية

\begin{tabular}{|c|c|c|c|c|c|c|c|}
\hline \multirow{2}{*}{$\begin{array}{c}\text { قيمة } \\
\text { L.S.D }\end{array}$} & \multicolumn{3}{|c|}{ الفروق بين المتوسطات } & \multirow[b]{2}{*}{ المتوسطات } & \multirow[b]{2}{*}{ القياسات المتكررة } & \multirow{2}{*}{ القياس } & \multirow{2}{*}{ لذكاءات المتعددة الدلالات الإحصائية } \\
\hline & البعدي القياس & القياس البينى & القياس القبلى & & & & \\
\hline \multirow{3}{*}{1.22} & $\uparrow * 6.77$ & $\uparrow * 2.62$ & & 17.43 & القياس القبلى & \multirow{3}{*}{ (درجة) } & \multirow{3}{*}{ الأكاء اللغوي } \\
\hline & $\uparrow * 4.15$ & & & 20.05 & القياس البينى & & \\
\hline & & & & 24.20 & القياس البعدي & & \\
\hline \multirow{3}{*}{0.99} & $\uparrow * 6.01$ & $\uparrow * 2.08$ & & 17.64 & القياس القبلى & \multirow{3}{*}{ (درجة) } & \multirow{3}{*}{ الأكاء الرياضياتى } \\
\hline & $\uparrow * 3.93$ & & & 19.72 & القياس البينى & & \\
\hline & & & & 23.65 & القياس البعدي & & \\
\hline \multirow{3}{*}{0.58} & $\uparrow * 6.47$ & $\uparrow * 2.12$ & & 18.23 & القياس القبلى & \multirow{3}{*}{ (درجة) } & \multirow{3}{*}{ الأكاء المكاني } \\
\hline & $\uparrow * 4.35$ & & & 20.35 & القياس البينى & & \\
\hline & & & & 24.70 & القياس البعدي & & \\
\hline \multirow{3}{*}{0.78} & $\uparrow * 7.17$ & $\uparrow * 2.40$ & & 18.13 & القياس القبلى & \multirow{3}{*}{ (درجة) } & \multirow{3}{*}{ الأكاء الحركي } \\
\hline & $\uparrow * 4.77$ & & & 20.53 & القياس البينى & & \\
\hline & & & & 25.30 & القياس البعدي & & \\
\hline \multirow{3}{*}{0.69} & $\uparrow * 8.11$ & $\uparrow * 2.91$ & & 17.24 & القياس القبلى & \multirow{3}{*}{ (درجة) } & \multirow{3}{*}{ الأكاء الموسيقى } \\
\hline & $\uparrow * 5.20$ & & & 20.15 & القياس البينى & & \\
\hline & & & & 25.35 & القياس البعدي & & \\
\hline \multirow{3}{*}{0.94} & $\uparrow * 6.60$ & $\uparrow * 2.80$ & & 18.95 & القياس القبلى & \multirow{3}{*}{ (درجة) } & \multirow{3}{*}{ الذكاء الإجتماعى } \\
\hline & $\uparrow * 3.80$ & & & 21.75 & القياس البينى & & \\
\hline & & & & 25.55 & القياس البعدي & & \\
\hline \multirow{3}{*}{0.87} & $\uparrow * 6.81$ & $\uparrow * 2.53$ & & 18.89 & القياس القبلى & \multirow{3}{*}{ (درجة) } & \multirow{3}{*}{ الأكاء الشخصي } \\
\hline & $\uparrow * 4.29$ & & & 21.42 & القياس البينى & & \\
\hline & & & & 25.71 & القياس البعدي & & \\
\hline \multirow{3}{*}{7.56} & $\uparrow * 47.94$ & $\uparrow * 17.45$ & & 126.52 & القياس القبلى & \multirow{3}{*}{ (درجة) } & \multirow{3}{*}{ مجموع الأكاءات } \\
\hline & $\uparrow * 30.49$ & & & 143.97 & القياس البينى & & \\
\hline & & & & 174.46 & القياس البعدي & & \\
\hline
\end{tabular}

*الفرق بين المتوسطين معنوي عند مستوى 0 . . 


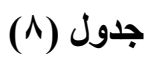

نسب تحسن الفروق بين متوسطات الذكاءات المتعدة لاى قياسات البحث الثلاثة خلال فترة التجربة للمجموعة التجريبية

\begin{tabular}{|c|c|c|c|c|c|c|}
\hline \multicolumn{3}{|c|}{ نسب تحسن الفروق بين المتوسطات } & \multirow{2}{*}{ المتوسطات } & \multirow{2}{*}{ المتكررة } & \multirow{2}{*}{ القياس } & \multirow{2}{*}{ الذكاءات المتعددة الالالات الإحصائية } \\
\hline القياس البعدي & القياس البينى & القياس القبلى & & & & \\
\hline$\% 38.83$ & $\% 15.02$ & & 17.43 & القياس القبلى & \multirow{3}{*}{ (درجة) } & \multirow{3}{*}{ الذكاء اللغوي } \\
\hline \multirow[t]{2}{*}{$\% 20.70$} & & & 20.05 & القياس البينى & & \\
\hline & & & 24.20 & القياس البعدي & & \\
\hline$\% 34.06$ & $\% 11.77$ & & 17.64 & القياس القبلى & \multirow{3}{*}{ (درجة) } & \multirow{3}{*}{ الأكاء الرياضياتى } \\
\hline \multirow[t]{2}{*}{$\% 19.94$} & & & 19.72 & القياس البينى & & \\
\hline & & & 23.65 & القياس البعدي & & \\
\hline$\% 35.49$ & $\% 11.63$ & & 18.23 & القياس القبلى & \multirow{3}{*}{ (درجة) } & \multirow{3}{*}{ الأكاء المكاني } \\
\hline \multirow[t]{2}{*}{$\% 21.38$} & & & 20.35 & القياس البينى & & \\
\hline & & & 24.70 & القياس البعدي & & \\
\hline$\% 39.55$ & $\% 13.24$ & & 18.13 & القياس القبلى & \multirow{3}{*}{ 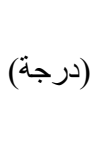 } & \multirow{3}{*}{ الأكاء الحركي } \\
\hline \multirow{2}{*}{$\% 23.23$} & & & 20.53 & القياس البينى & & \\
\hline & & & 25.30 & القياس البعدي & & \\
\hline$\% 47.01$ & $\% 16.85$ & & 17.24 & القياس القبلى & \multirow{3}{*}{ 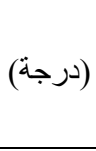 } & \multirow{3}{*}{ الأكاء الموسيقى } \\
\hline \multirow[t]{2}{*}{$\% 25.81$} & & & 20.15 & القياس البينى & & \\
\hline & & & 25.35 & القياس البعدي & & \\
\hline$\% 34.85$ & $\% 14.78$ & & 18.95 & القياس القبلى & \multirow{3}{*}{ (درجة) } & \multirow{3}{*}{ الأكاء الإجتماعى } \\
\hline \multirow[t]{2}{*}{$\% 17.49$} & & & 21.75 & القياس البينى & & \\
\hline & & & 25.55 & القياس البعدي & & \\
\hline$\% 36.06$ & $\% 13.38$ & & 18.89 & القياس القبلى & \multirow{3}{*}{ (درجة) } & \multirow{3}{*}{ الأكاء الثخصي } \\
\hline \multirow[t]{2}{*}{$\% 20.01$} & & & 21.42 & القياس البينى & & \\
\hline & & & 25.71 & القياس البعدي & & \\
\hline$\% 37.89$ & $\% 13.79$ & & 126.52 & القياس القبلى & \multirow{3}{*}{ (درجة) } & \multirow{3}{*}{ مجموع الذكاءات المتعددة } \\
\hline$\% 21.18$ & & & 143.97 & القياس البينى & & \\
\hline & & & 174.46 & القياس البعدي & & \\
\hline
\end{tabular}

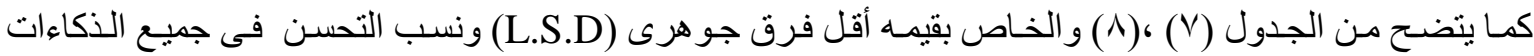

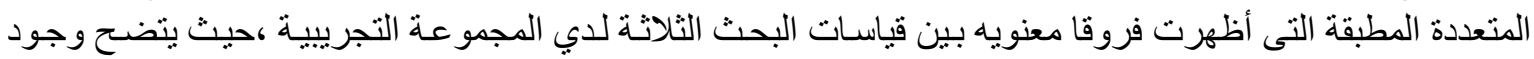

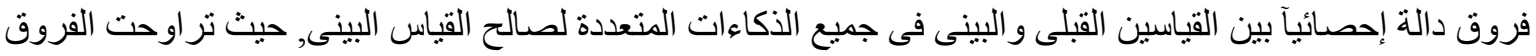

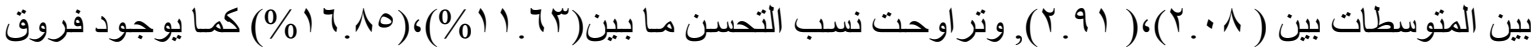

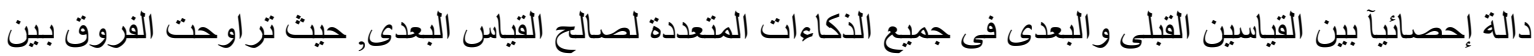

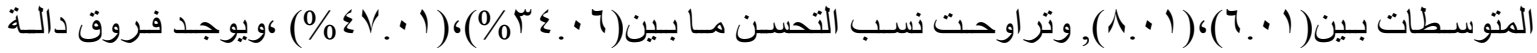

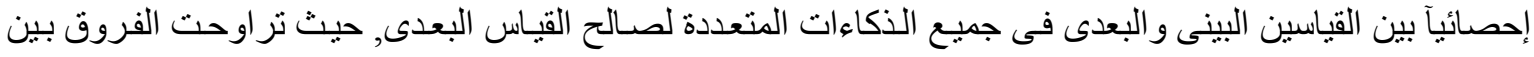

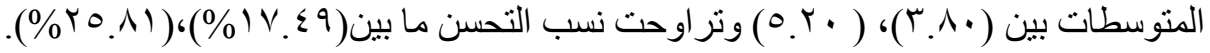


r. عرض النتائج الخاصة بدرجات تقييم المحكين لمستوى أداء العرض الرياضى للمجموعة التجريبية:

$$
\text { جدول (9) جمنول }
$$

الالالات الاحصائية الخاصة بدرجات تقييم المحكمين لمستوى أداء العرض الرياضى للمجموعة التجريبية قبل وبعد

$$
\text { التجربة }
$$

\begin{tabular}{|c|c|c|c|c|c|c|c|c|c|c|c|c|}
\hline \multirow{3}{*}{ كوهن } & \multirow{3}{*}{ צ' } & \multirow{3}{*}{ التحسنة\% } & \multirow{3}{*}{$\begin{array}{c}\text { قيمة } \\
\text { *14.20 }\end{array}$} & \multicolumn{2}{|c|}{ المتوسطات بين } & \multicolumn{2}{|c|}{ القياس البعدى } & \multicolumn{2}{|c|}{ القياس القبلي } & \multirow{3}{*}{ لدرجة } & \multirow{2}{*}{\multicolumn{2}{|c|}{ محاور تقيي للإلاضلات الإحصائية }} \\
\hline & & & & $\varepsilon^{ \pm}$ & سن س & $\varepsilon^{ \pm}$ & سنَ & $\varepsilon^{ \pm}$ & سن س & & & \\
\hline & & & & 0.35 & -2.20 & 0.11 & 4.88 & 0.39 & 2.68 & & الاخول & \\
\hline 1.70 & $\cdot 9 v$ & $\% 91.67$ & *38.41 & 0.41 & -7.04 & 0.44 & 14.72 & 0.18 & 7.68 & درجة 10 & والتثكيلات & الأولور \\
\hline $9 . \% 0$ & .911 & $\% 89.19$ & $* 34.06$ & 0.61 & -9.24 & 0.35 & 19.60 & 0.46 & 10.36 & درجة & المجموع & \\
\hline 7.57 & .99 & $\% 64.10$ & *10.11 & 0.66 & -3.00 & 0.44 & 7.68 & 0.39 & 4.68 & درجات & المتسلسل & \\
\hline r & $.9 V$ & $\% 89.05$ & $* 10.58$ & 0.76 & -3.58 & 0.55 & 7.60 & 0.30 & 4.02 & $\begin{array}{c}\wedge \\
\text { درجات }\end{array}$ & الحركيابية & \\
\hline $9 . Y \wedge$ & .97 & $\% 195.52$ & $* 44.93$ & 0.26 & -5.24 & 0.11 & 7.92 & 0.18 & 2.68 & $\begin{array}{c}\wedge \\
\text { درجات }\end{array}$ & الصعوبات & الثانى \\
\hline $7 . \wedge 7$ & $\cdot \wedge q$ & $\% 77.67$ & *13.06 & 0.55 & -3.20 & 0.63 & 7.32 & 0.11 & 4.12 & درجات & التوظيف & (الفنى) \\
\hline 9.90 & .90 & $\% 96.90$ & *33.89 & 0.99 & $\begin{array}{c}- \\
15.02\end{array}$ & 0.69 & 30.52 & 0.55 & 15.50 & درجة & المجموع & \\
\hline $.03 r$ & $\cdot \wedge \theta$ & $\% 28.42$ & $* 6.00$ & 0.80 & -2.16 & 0.33 & 9.76 & 0.55 & 7.60 & درجات & الملابس & \\
\hline $7.5^{\circ}$ & 89 . & $\% 18.46$ & $* 4.78$ & 1.03 & -2.20 & 0.52 & 14.12 & 0.72 & 11.92 & درجة 10 & الموسيقى & الثحالثر \\
\hline V.ro & .94 & $\% 22.34$ & *9.02 & 1.08 & -4.36 & 0.67 & 23.88 & 0.58 & 19.52 & درجة & المجموع & \\
\hline$r . V \leq$ & $\cdot .9 \leq$ & $\% 18.71$ & $* 7.98$ & 0.62 & -2.20 & 0.65 & 13.96 & 0.22 & 11.76 & درجة 10 & الإخراج & \\
\hline$\because \cdots$ & 0.00 & 0.00 & 0.00 & 0.00 & 0.00 & 0.00 & 5.00 & 0.00 & 5.00 & $\begin{array}{c} \\
\text { درجات }\end{array}$ & العرض & المحور \\
\hline r.r. & $.9 v$ & $\% 69.77$ & $* 10.52$ & 0.25 & -1.20 & 0.11 & 2.92 & 0.22 & 1.72 & درجات & الخروج & الرابع \\
\hline $7 . \leqslant 0$ & .90 & $\% 18.40$ & *14.24 & 0.53 & -3.40 & 0.70 & 21.88 & 0.36 & 18.48 & درجة & المجموع & \\
\hline 1.79 & 0.99 & $\% 50.14$ & *70.65 & 1.01 & $\begin{array}{c}- \\
32.02\end{array}$ & 0.54 & 95.88 & 0.66 & 63.86 & درجة & يموع للعرض & الارجة \\
\hline
\end{tabular}

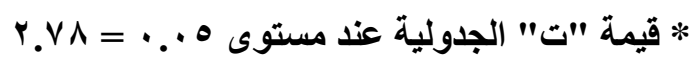

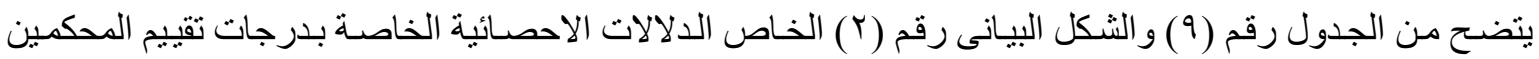

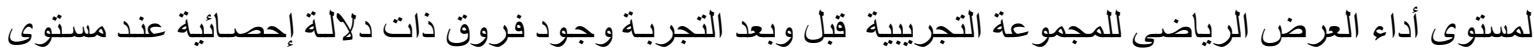


(0 •. • ) فى جميع العناصر ما عدا عنصر الزمن لصالح القياس البعدى ، حيث تراوحت قيمة (ت ) المحسوبة مـا بين

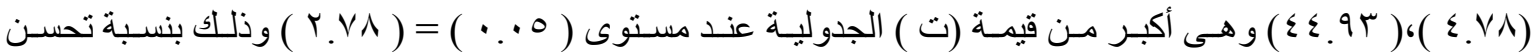

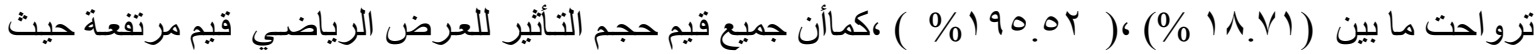

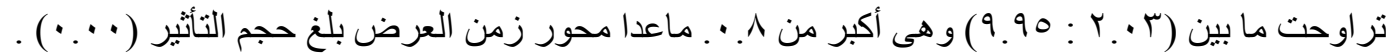

\section{شكل (r)}

المتوسط الحسابى للقياس القبلي والبعدى فى درجات تقييم المحكمين لمستوى أداء العرض الرياضى للمجموعة التجريبية

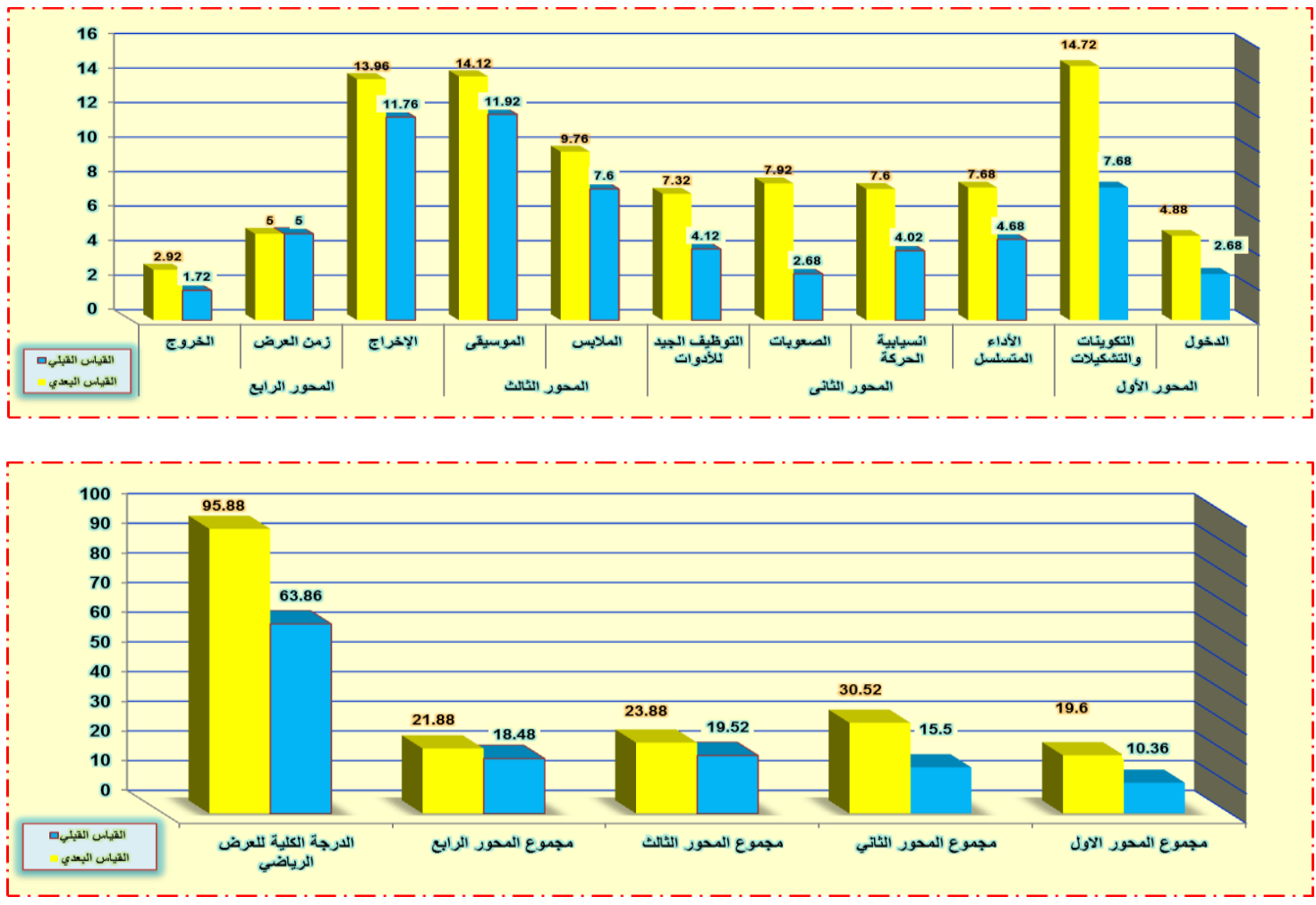

r. عرض النتائج الخاصـة بمعامـل الارتبـاط بين الذكاعات المتعددة و عناصر تقيّيم المحكمين لمستوى أداء العرض الرياضى للمجموعة التجريبية:

جدول (·) (1)

معامل الارتباط بين الأكاءات المتعددة و عناصر تقييم المحكمين لمستوى أداء العرض الرياضى قيل البحث ن=.

\begin{tabular}{|c|c|c|c|c|c|c|c|c|c|}
\hline الأكاءات & الثخصي & الإجتماعى & الموسيقى الأكاء & الحركي & المكاني & الرياضياتى & اللغوي & يبيم العرض الرياضمى الأكاءات المتعلدة & \\
\hline$* 0.789$ & $* 0.657$ & $* 0.765$ & $* 0.784$ & $* 0.769$ & $* 0.724-$ & $* 0.784$ & $* 0.771$ & الاخول & \multirow{3}{*}{ الأولور } \\
\hline *0.665- & $* 0.815$ & $* 0.841$ & $* 0.684$ & $* 0.765$ & $* 0.738$ & $* 0.753$ & $* 0.712$ & التكوينات والتشكيلات & \\
\hline *0.649- & $* 0.684$ & $* 0.784$ & $* 0.797$ & $* 0.841$ & $* 0.739$ & $* 0.779$ & $* 0.663$ & المجموع & \\
\hline$* 0.640-$ & $* 0.657$ & $* 0.765$ & $* 0.604$ & $* 0.784$ & $* 0.747$ & $* 0.787$ & $* 0.785$ & الأداء المتسلسل & \multirow{3}{*}{ (الأثانى } \\
\hline$* 0.795$ & $* 0.815$ & $* 0.841$ & $* 0.665-$ & $* 0.853$ & $* 0.765-$ & *0.657 & $* 0.765$ & انسيابية الحركة & \\
\hline *0.642- & $* 0.684$ & $* 0.784$ & *0.649- & $* 0.779$ & $.755-$ & $* 0.815$ & $* 0.841$ & الصعوبات & \\
\hline
\end{tabular}




\begin{tabular}{|c|c|c|c|c|c|c|c|c|c|}
\hline 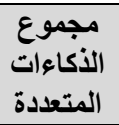 & الثخصي & الإجتماعى الأكاء & الموسيقى & الحركي & المكاني & الرياضياتى & الغ الذوي & الأكاءات المتعددة & \\
\hline & & & & & $*$ & & & الفن، مناصر تقييم العرض الرياضمى & \\
\hline$* 0.715$ & *0.657 & $* 0.765$ & $* 0.640$ & $* 0.785$ & *0.797- & $* 0.684$ & *0.784 & التوظيف الجيات & \\
\hline *0.635- & $* 0.815$ & $* 0.841$ & $* 0.795$ & $* 0.765$ & *0.779- & $* 0.753$ & $* 0.753$ & المجموع & \\
\hline 0.245 & 0.110 & 0.230 & 0.010 & 0.310 & $* 0.198$ & $* 0.149$ & 0.210 & الملابس & \multirow{3}{*}{ الثالث } \\
\hline *0.667- & *0.797- & $* 0.684$ & $* 0.784$ & *0.784 & $* 0.660-$ & $* 0.777$ & $* 0.787$ & الموسيقى & \\
\hline$* 0.680$ & *0.799. & $* 0.780$ & *0.789 & $* 0.753$ & $* 0.739$ & *0.757 & $* 0.657$ & المجموع & \\
\hline$* 0.745$ & *0.791- & $* 0.684$ & $* 0.784$ & $* 0.779$ & $* 0.590$ & $* 0.815$ & $* 0.815$ & الإخراج & \multirow{4}{*}{ المرابع } \\
\hline 0.020 & 0.243 & $\because 1 Y r$ & 0.232 & 0.203 & 0.124 & $* 0.213$ & $* 0.223$ & زمن العرض & \\
\hline$* 0.767$ & *0.789- & $* 0.784$ & $* 0.884$ & $* 0.795$ & $* 0.707$ & $* 0.841$ & $* 0.885$ & الخروج & \\
\hline$* 0.763$ & *0.790- & $* 0.684$ & *0.784 & $* 0.642-$ & *0.641- & *0.784 & *0.787 & المجموع & \\
\hline$* . .996$ & $* .967$ & $* . .994$ & $* .981$ & $* .986$ & $\begin{array}{l}.969- \\
*\end{array}$ & $* .939$ & $* .965$ & \multicolumn{2}{|c|}{ الارجة الكلية للعرض } \\
\hline
\end{tabular}

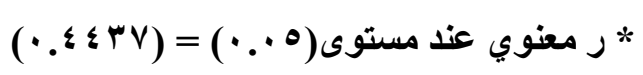

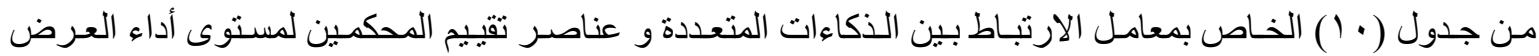

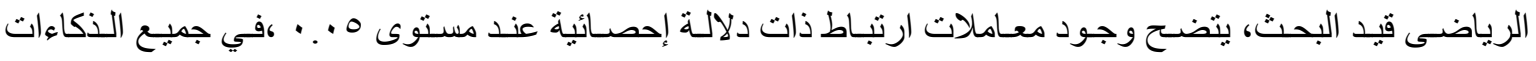

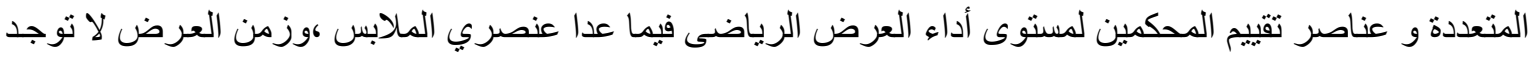

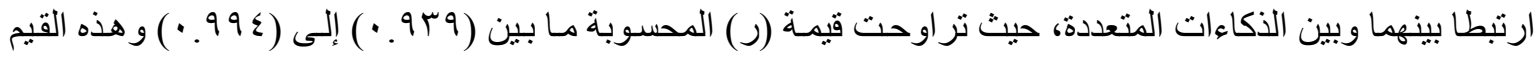
أكبر من قيمة (ر) الجدولية، مما بدل على الارتباط الوثيق بين الذكاءات المتعددة و عناصر تقييم المحكمين لمستوى أداء العرض الرياضى قيد البحث.

مناقشة النتائج

من خـلال العرض السـابق لنتـائج البحث يتضـح وجود فروق ذات دلالـة إحصـائية فى قائمسة الذكاءات المتعددة تحسن

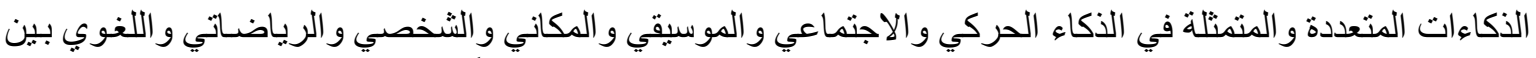

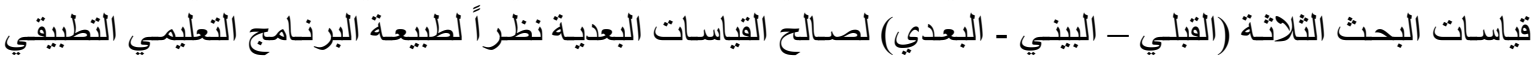
المستخدم، كما أن التدريب المنظم وتكرار الأداء لتمرينات العرض أدئ أدى الي تحسين مستوي الأداء، و هذا يتفق مـع نتائج

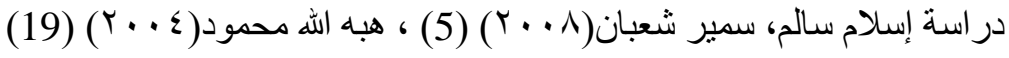

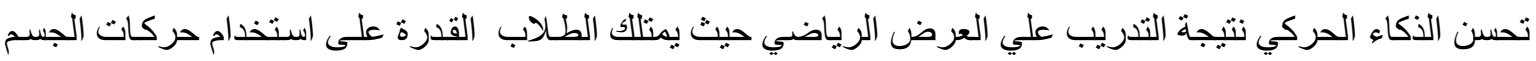

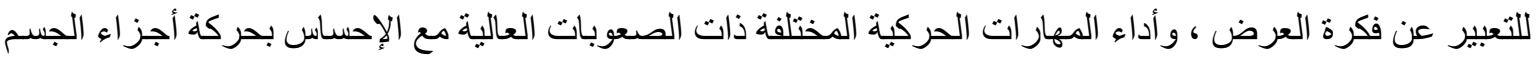

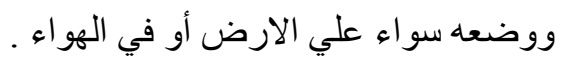

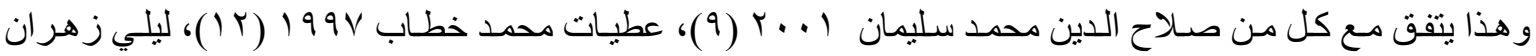

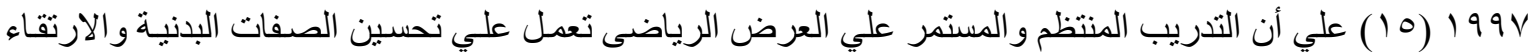
بالأداء الحركي للمشتركين في العرض. أن إن.

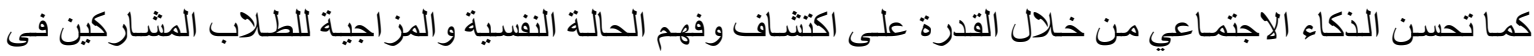

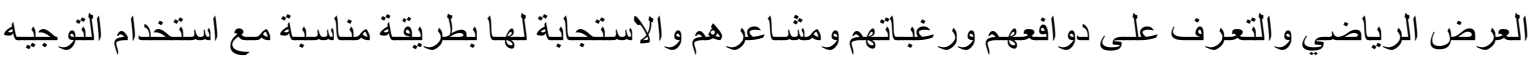

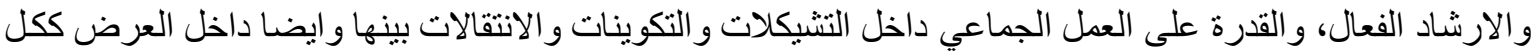
مما أدي الي تفاعل الطلاب مع بعض البعض عل العمل الجياعي أداء العرض الرئني 


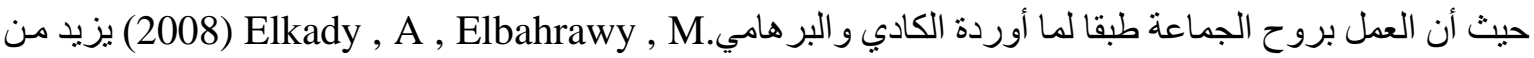

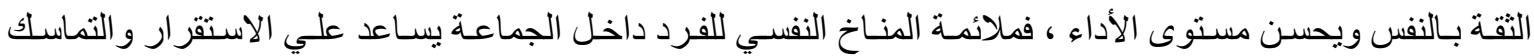

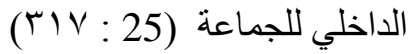

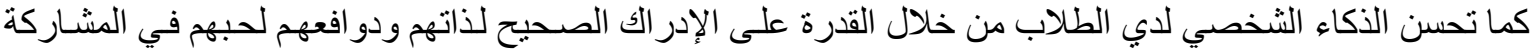

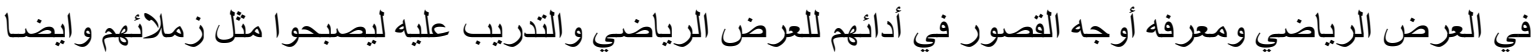

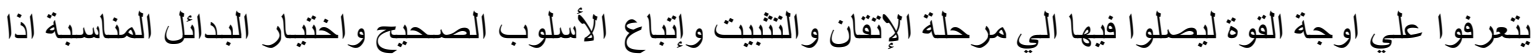

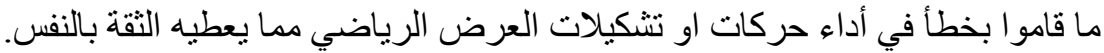

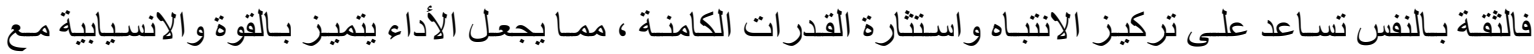

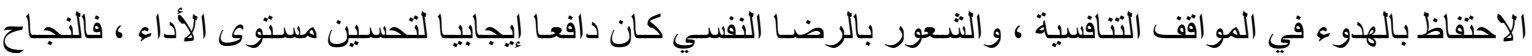

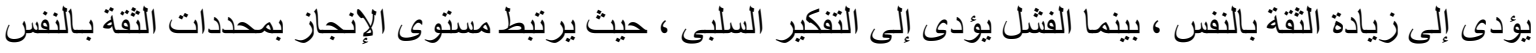

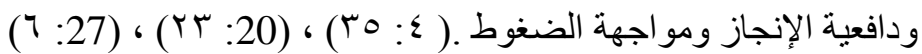

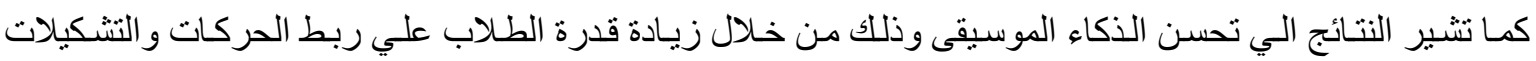

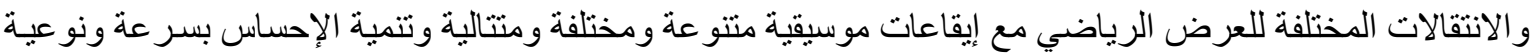

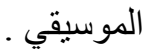

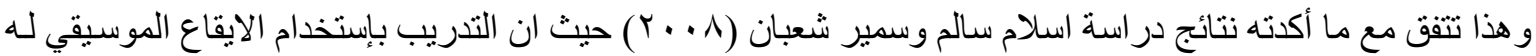

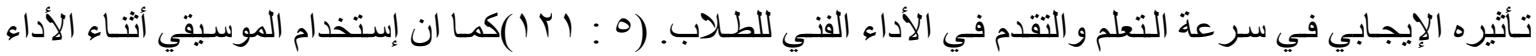

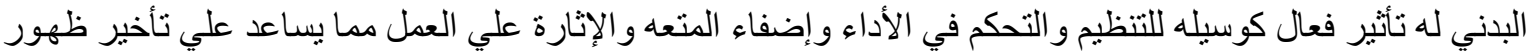

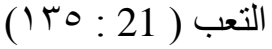

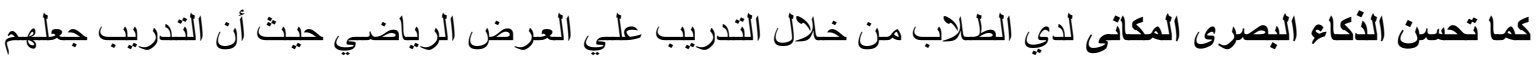

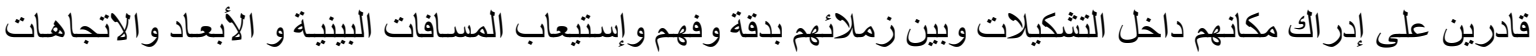

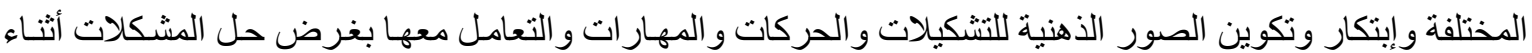
أدائهم للعرض الرياضي.

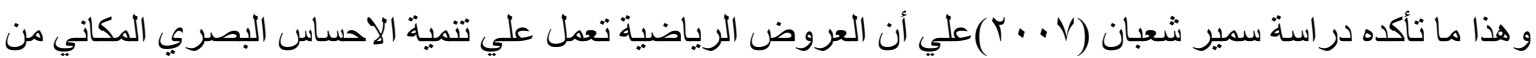

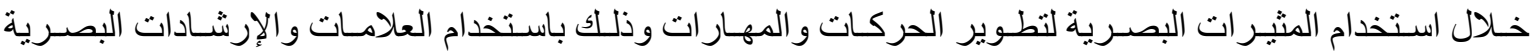

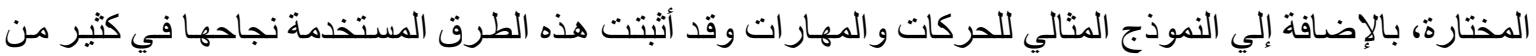

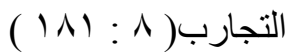

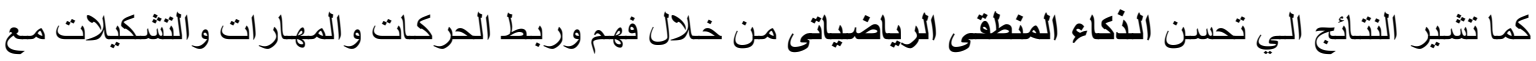
بعضها البعض وايضا بين الايقاع الموسيقي و إكتثاف النماذج الصحيحة من قبل المدرب أو أحد الطلاب المتميزين

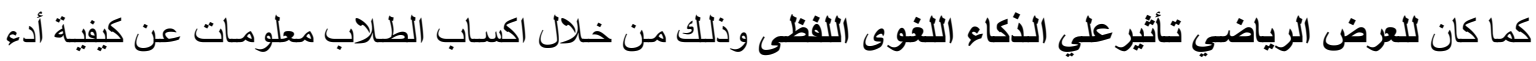

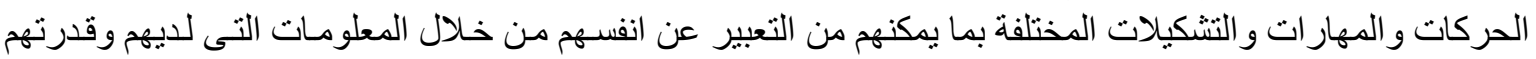
علي فهم طبيعة الحركات و المهار ات و التشكيلات بطـلاقة وبلغة سهلة ومفهو مـــه.

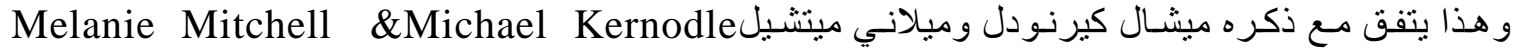

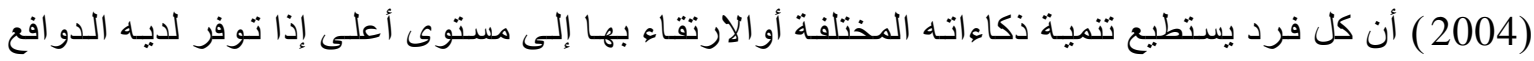

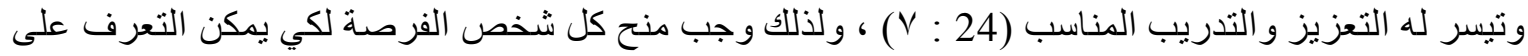

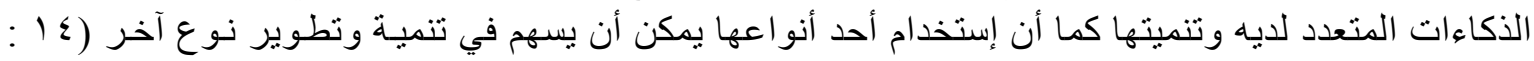




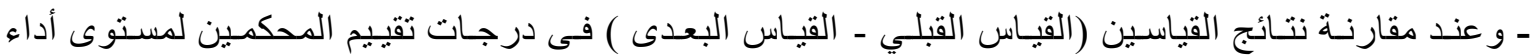

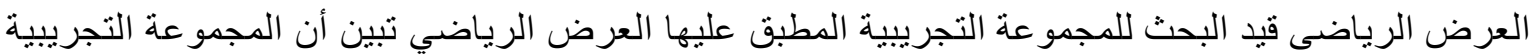

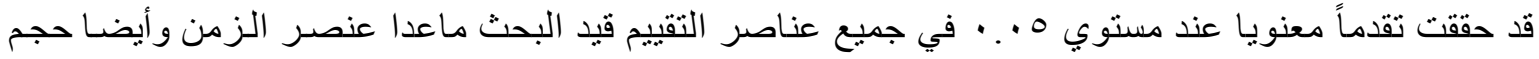

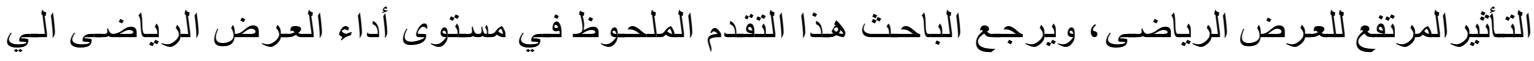

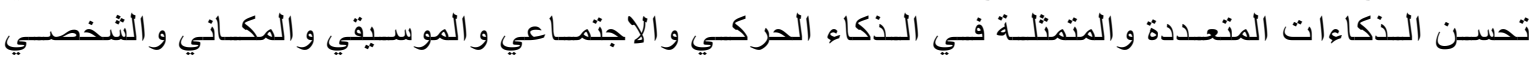

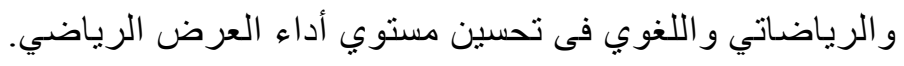

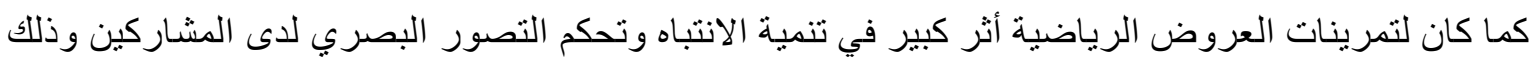

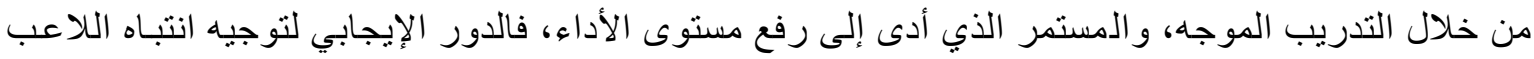

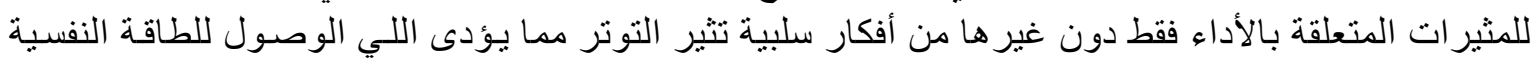

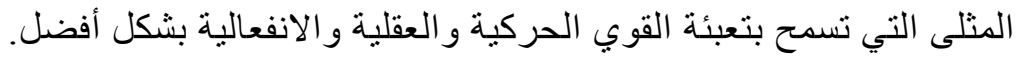

$$
(\text { ( } 99: r) \cdot(1 \wedge r: 1)
$$

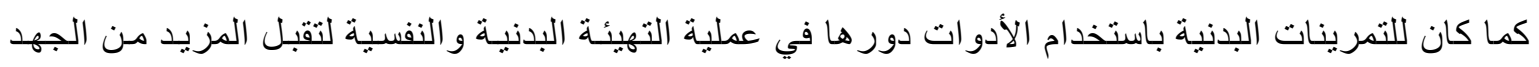

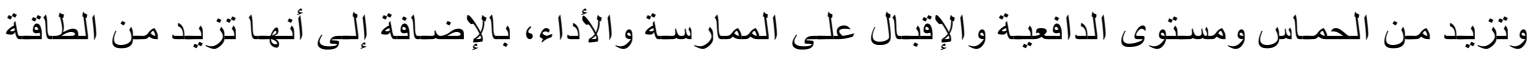

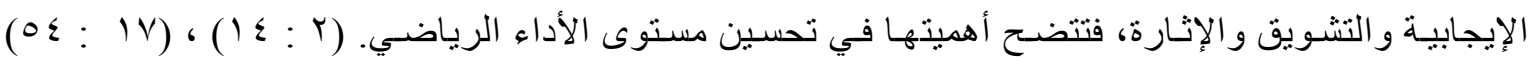

ـ حققت المجموعة التجريبية تفوقا في القياسات البعدية على القياسات القبلية في قائمة الذكاءات المتعددة (الذكاء

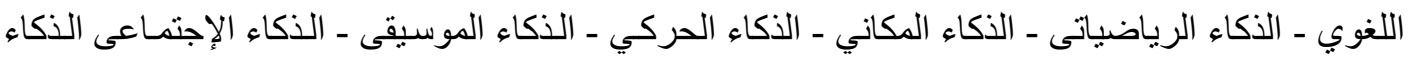

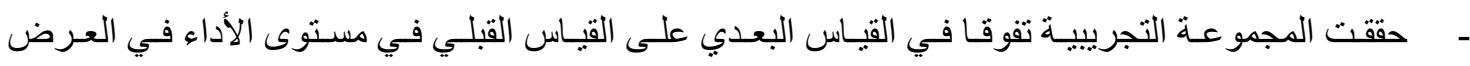
الرياضي.

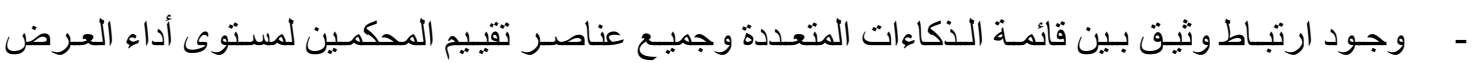

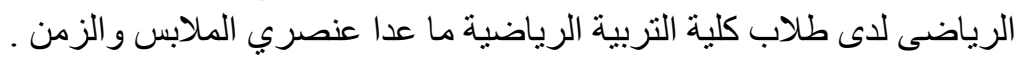

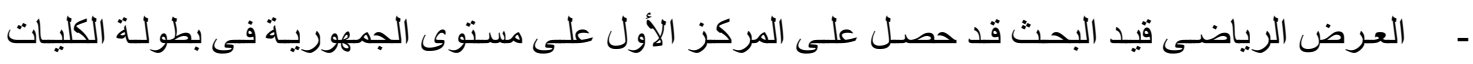

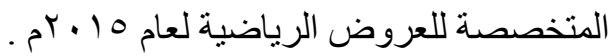

- توجيه الطلاب للاشتر اك في العروض الرياضية و التي تسهم في تحسين أنواع الذكاءات المتعددة.

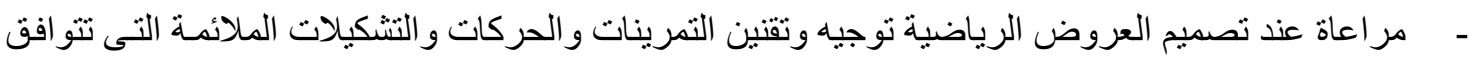

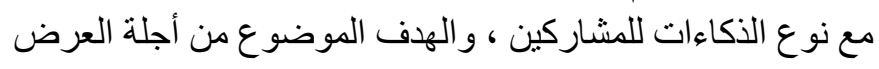
- إجر اء در اسات أخرى لمعرفة تأثير العروض الرياضية على الجوانب النفسية الأخرى. - وضع بر امج تمرينات أخرى ومعرفة تأثثير ها على الجوانب النفسية الأخرى. - أيضا الإهتمام بتنظيم العروض الرياضية و المشاركة بها في جميع المناسبات. 


\section{أولاً :المراجع العربية:}

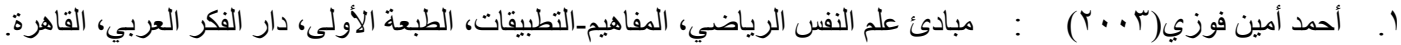

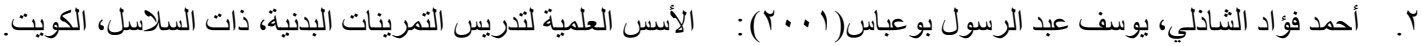

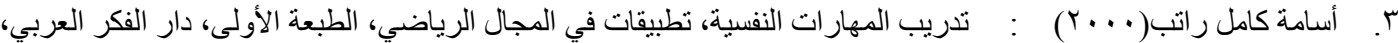

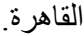

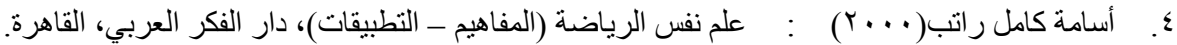

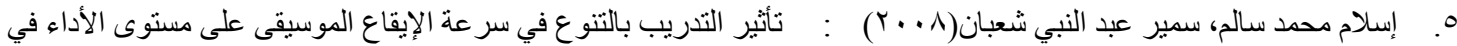
العروض الرياضية، المؤتمر الإقليمي الرابع للمجلس الدولي للصحة والتربية البدنية والترويح والرياضة و التعبير الحركي لمنطقة الثرق الأوسط، الجزء الثالث، كلية التربية الرياضية ـأبو قير ، جامعه الإسكندرية ، مصر.

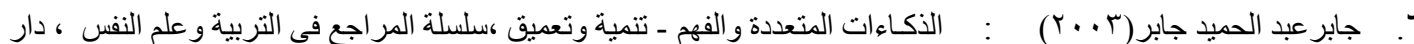

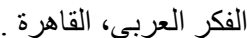

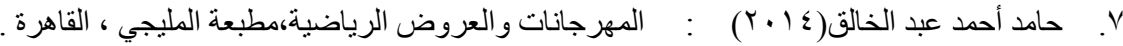

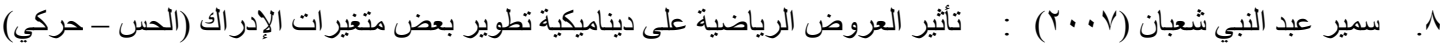
ومستوى التحصيل العملي في التمرينات بالأدوات لطلاب كلية التربية الرياضية، رسالة دكتور اه، كلية التربية الرياضية، جامعة الإسكندرية.

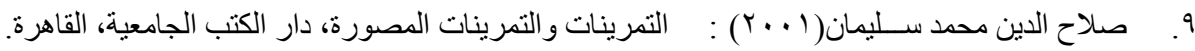
• 1. عبد المنعم سليمان بر هم، محمد خميس أبو نمرة(1990) : موسو عة التمرينات الرياضية، الجزء الأول، الطبعة الثانية، دار الفكر للنشر و التوزيع، القاهرة.

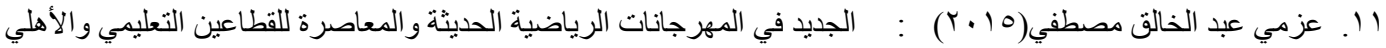
كأساسيات .أداء. تطبيقات .ثقافة ،منشأة المعارف ,الاسكندرية .

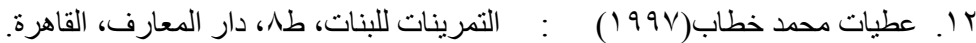

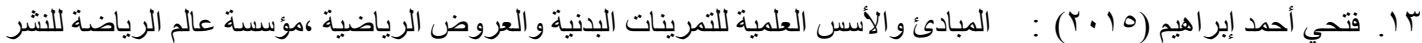
الأسكندرية.

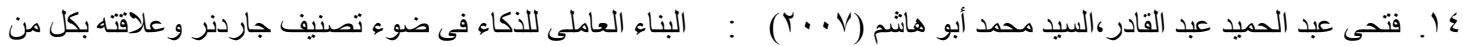

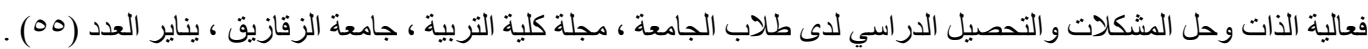

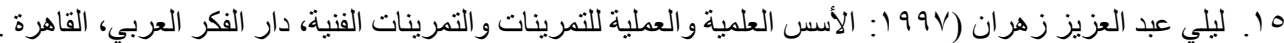

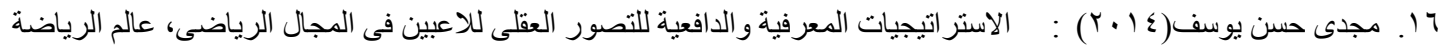
للطبع و النشر، طا ،الاسكندرية .

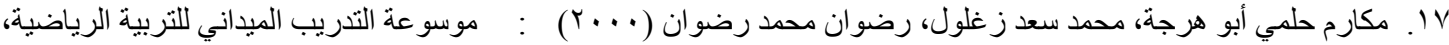
مركز الكتاب للنشر، القاهرة.

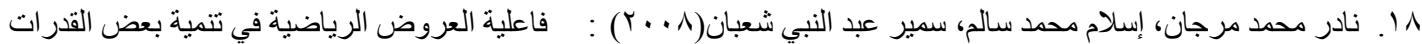
الحركية ومفردات التكيف النفسي لاي طلاب كلية التربية الرياضية، المؤتمر الإقليمي الر ابع للمجلس الدولي للصحة والتربية البدنية 
و الترويح و الرياضة و التعبير الحركي لمنطقة الثرق الأوسط، الجزء الثاني، كلية التربية الرياضية ـأبوقير، جامعة الإسكندرية،

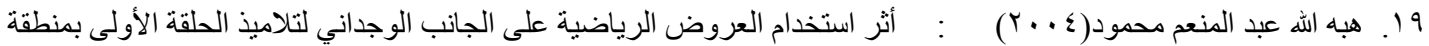

شرق طنطا التعليمية، رسالة ماجستير، كلية التربية الرياضية للبنين، جامعه الإسكندرية..

\section{ثانياً :المراجع الأجنبية:}

20. Fuerst, M \&Levy. A.( 1993) Sport injury hand, professional advice for amateur athletes, John wiley and sons, I.N.C, U.S.A.,.

21. Gardner, H. (1983) Multiple intelligences. New York: Basic Books.

22. Gardner, H. (1999) Intelligence Reframed: Multiple Intelligence for the 21st Century. New York: Basic Books.

23. Magdy Hassan Yousef (2010) Footprint of Multiple Intelligences of the Faculty of Physical Education Male Students Alexandria University According to the Standard Academic Measures, World Journal of Sport Sciences 3 (2) 125-134.

24. Michael Kernodle, Melanie Mitchell (2004) Using Multiple Intelligences to Teach Tennis: The Theory of Multiple Intelligences Has Wide Application, but Few Articles Have Discussed How to Use It to Improve the Teaching of a Specific Unit in Physical Education. Journal article by Melanie Mitchell, Michael Kernodle; Joperd--The Journal of Physical Education, Recreation \& Dance, Vol. 75 ,

25. Elkady, A ., Elbahrawy, M.( 2008) The relationship between mental toughness, athletic coping skills inventory and achievement level among swimmers, 18th world congress of the international association for child and adolescent psychiatry and allied professions ( IACAPAP ), Istanbul, Turkey .

26. Haglind, D.( 2004) Coping with success and failure-A qualitative study on athletes and coaches in track and field, (essay in sport psychology) school of social and health science. Halmstad University, PP 41-60, .

27. Lefkowits, J. , McDuff,D., \& Riismandel,C.( 2003) Mental toughness training manual for soccer , Article sports Dynamics, United Kingdom,. 


\section{الملخص باللغة العربيـة}

أثر ممارسة العروض الرياضية في بعض الذكاءات المتعددة وعلاقتها بمستوي الأداء للدي طلاب كلية التربية الرياضية.

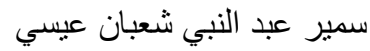

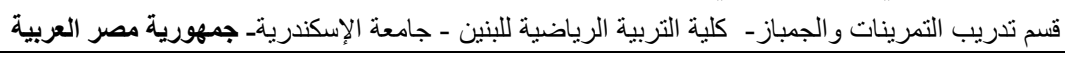
يهدف البحث الي التعرف علي أثر ممارسة العروض الرياضية في بعض الذكاءات المتعددة و علاقتها بمستوي الأداء لدي طلاب كلية التربية

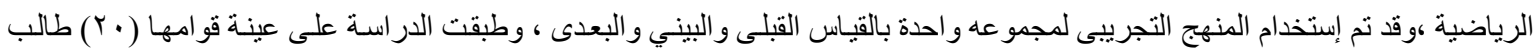

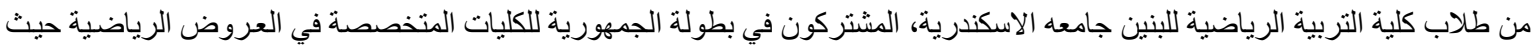

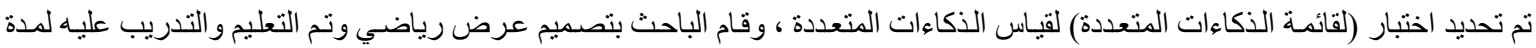

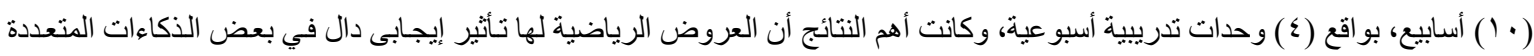

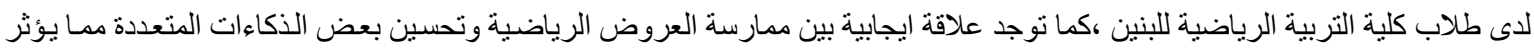

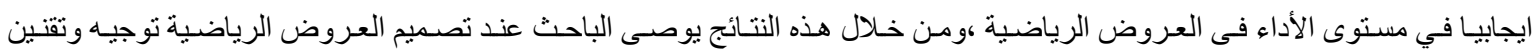

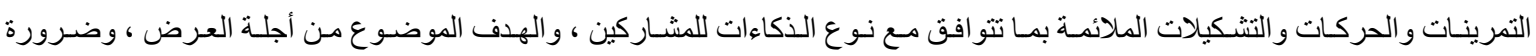
الإثنتر الك فى العروض الرياضية والنى تساعد فى تحسين أنواع الذكاءات المتعددة. 


\section{الملخص باللغة الإنـليزيـة}

The Effeet of Practieing Sport Shows in some of the multiple intelligenees and their relationship to the level of performance in Students of the Faculty of Physical Education.

\section{Samir Ahdel-Nabi Shaaban Essa}

The research aims to identify the impact of the sports performances in some of the multiple intelligences and their relationship to the level of performance of the Faculty of Physical Education students, has been using the experimental method to a total of one measurement tribal and intra and post test, and applied study on a sample of 20 students from the students of the Faculty of Physical Education for Boys University Alexandria, participants in the Republic Championship colleges specialized in sports performances where identification test (for a list of multiple intelligences) to measure multiple intelligences, and the researcher to design a sports show was education and training for 10 weeks, the rate of (4) training modules weekly, and the most important results the sport offers a positive effect D. in some multiple intelligences among students of the Faculty of Physical Education for Boys, and there is a positive relationship between sports performances and improve some of multiple intelligences, which positively affect the level of performance in sports performances, and through these results is recommended researcher when designing sports performances directing and rationing exercise and proper movements and formations including intelligences are compatible with the type of participants, and the target set for him the show, and the need to participate in sporting performances which helps in improving the types of multiple intelligences. 
